Portland State University

PDXScholar

$1-1-2012$

\title{
Negative Transfer in the Writing of Proficient Students of Russian: A Comparison of Heritage Language Learners and Second Language Learners
}

Daria Aleeva

Portland State University

Follow this and additional works at: https://pdxscholar.library.pdx.edu/open_access_etds Let us know how access to this document benefits you.

\section{Recommended Citation}

Aleeva, Daria, "Negative Transfer in the Writing of Proficient Students of Russian: A Comparison of Heritage Language Learners and Second Language Learners" (2012). Dissertations and Theses. Paper 507.

https://doi.org/10.15760/etd.507

This Thesis is brought to you for free and open access. It has been accepted for inclusion in Dissertations and Theses by an authorized administrator of PDXScholar. Please contact us if we can make this document more accessible: pdxscholar@pdx.edu. 
Negative Transfer in the Writing of Proficient Students of Russian: A Comparison of Heritage Language Learners and Second Language Learners

by

Daria Aleeva

A thesis submitted in partial fulfillment of the requirements for the degree of

\author{
Master of Arts \\ in \\ Teaching English to Speakers of Other Languages
}

Thesis Committee:

Susan Conrad, Chair

Kathryn Harris

Sandra Freels

Portland State University

(C)2012 


\begin{abstract}
This study explored the phenomenon of negative transfer from English in the writing of proficient heritage vs. second language learners of Russian.

Although a number of studies have examined negative transfer from English into Russian, and other studies have compared the performance of heritage language learners (HLLs) to second language learners (SLLs), little research has investigated the phenomenon of negative transfer in the writing of both HLLs and SLLs and compared the two groups. Thus, this study employed an exploratory approach to empirically investigate the differences in language transfer between the two groups of learners. Specifically, the study addressed the following questions:
\end{abstract}

(1) What are the most common types of negative transfer from English that occur in the writing of students of Russian at the Intermediate High - Advanced levels?

(2) Are there differences in types and amount of negative transfer used by HLLs vs. SLLs at comparable levels of proficiency? If so, what are the differences?

The research was conducted at the Russian Flagship Program at Portland State University. Participants were 13 advanced students of Russian - 6 heritage speakers of Russian and 7 native speakers of English. The study analyzed the written work of students completed during one quarter. Errors were coded into 13 categories that emerged from the data and frequencies were compared between the groups. The results found that none of the errors were more frequent than 5 per 1000 words. The most common categories were semantic extension, commas after an introductory phrase, lexical borrowings, and null subject errors. However, some categories of errors were associated 
with only one group, SLL or HLL, and some were not. Specifically, the categories of null subject errors, loan translations, conjunction "yesli/li" (if/whether), adjectives for nationality, and negation errors were found only in the writing of second language learners. There were only two categories limited to the group of heritage language learners: conceptual shift and number errors. The categories of semantic extension, comma after an introductory phrase, lexical borrowings, reflexive possessive pronoun "svoj", capitalization, and preposition errors were found in writing of both groups of students. Overall, second language learners made more transfer errors that heritage learners.

Ultimately, this study will be of interest to anyone interested in heritage and second language acquisition of Russian, language transfer in learners of Russian, or the teaching of advanced language courses. 
Dedication

Моей семье: тем, кто научил меня думать, верить в себя и ничего не бояться. 


\section{Acknowledgements}

Working on this thesis research has been an invaluable experience. I would like to express my appreciation and gratitude to everyone who has made it possible.

First, I would like to thank my thesis advisor, Professor Susan Conrad. You have not only guided me through this long and challenging process but supported me every step of the way. You always had something nice to say about my drafts and that encouragement together with detailed feedback inspired me and helped me to keep going. Thank you from the bottom of my heart!

I want to also express my immense gratitude to Professor Sandra Freels. Thanks to you I have had a chance to be a part of the Russian Flagship Program. It not only allowed me to gain inestimable teaching experience but also provided me with an opportunity to bring together my TESOL training and Russian teaching, leading to this study. You have been my grand advisor for four years, and for that I will be forever grateful.

I would also like to acknowledge Professor Kathy Harris. Thank you for your support, encouragement, and invaluable feedback. And I will always be thankful to you for giving me inspiration to be a better teacher.

Thank you to the instructors and students of the Russian Flagship Program at PSU. Without your help and participation, this study would not have been possible.

Finally, I wish to thank all my family and friends in Portland and in Russia for their love and support; especially my loving mother who has always believed in me and inspired me to follow my dreams. Спасибо! 


\section{Table of Contents}

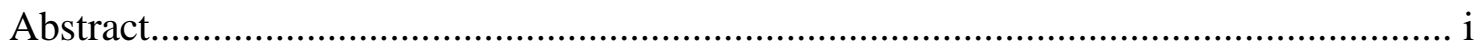

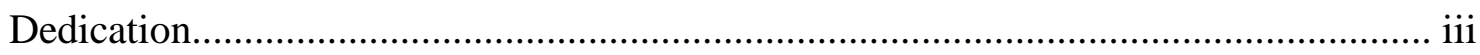

Acknowledgements..................................................................................... iv

List of Tables ..................................................................................................

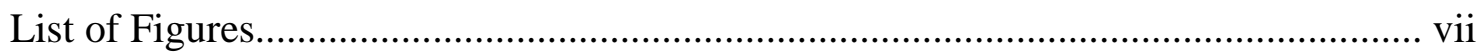

List of Abbreviations............................................................

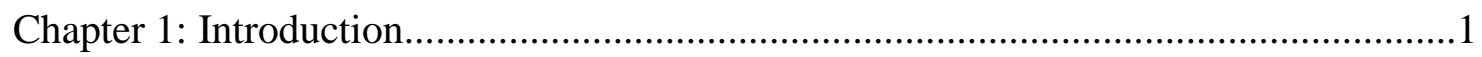

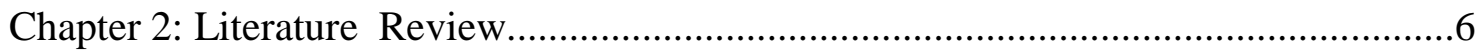

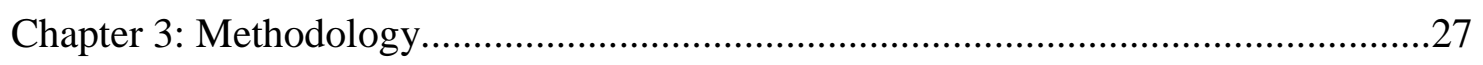

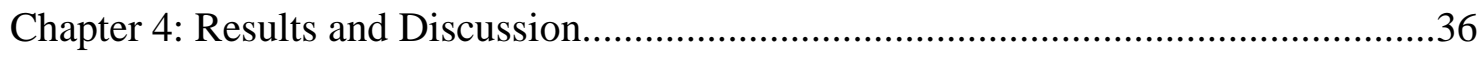

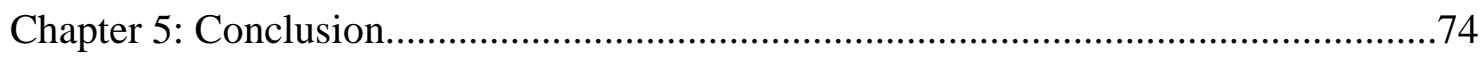

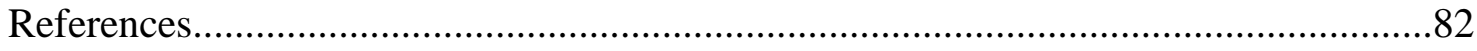

Appendices

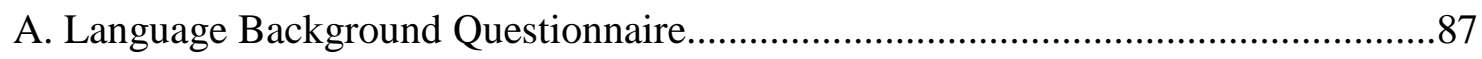

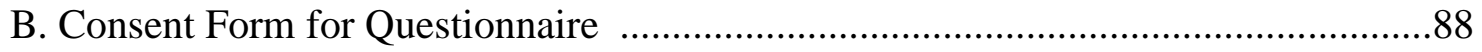

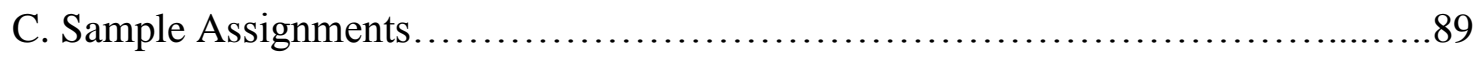




\section{List of Tables}

Table 2.1: Categories of bidirectional Russian-English transfer in adult Russian users of English (based on Pavlenko and Jarvis, 2002)................................

Table 2.2: L2 influence on L1 (based on Pavlenko, 2000)............................11

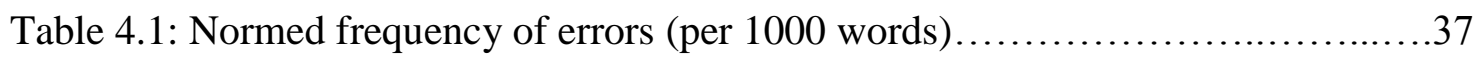

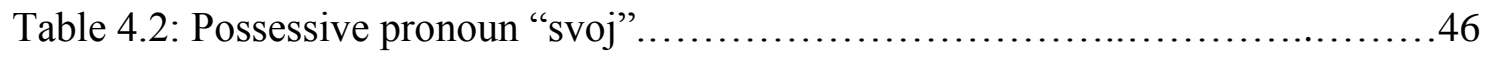

Table 4.3: Capitalization in Russian..........................................48 


\section{List of Figures}

Figure 4.1: The most common types of negative transfer from English that occurred in the writing of students of Russian at the Intermediate High - Advanced levels

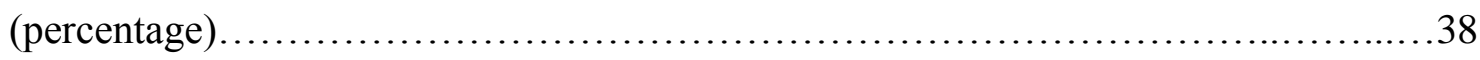

Figure 4.2: Types and amount of negative transfer used by HLLs vs. SLLs (percentages

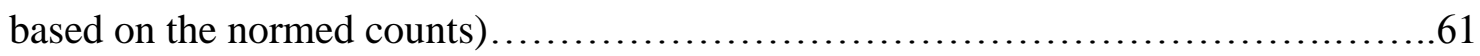




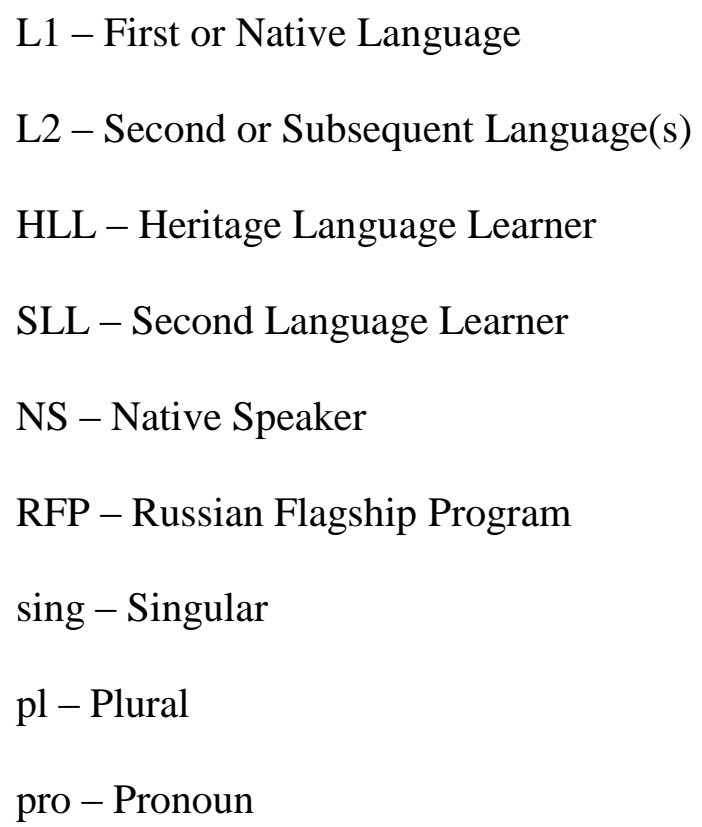




\section{CHAPTER 1}

\section{INTRODUCTION}

"Remember my Russian teacher? He used to tease me that he would never give me that ' $A$ ' if I keep speaking English with Russian words."

(a learner of Russian)

When I first came to the United States, I was surprised to hear a lot of people speaking a variety of Russian I had never heard before. To me it sounded like some sort of language hybrid or, as one of my students later described it, as if "Russian and English languages got married and had a baby." Later I realized that most people speaking that variety of Russian were heritage speakers of Russian and/or native speakers of English learning Russian as a second language.

As a linguist and a language teacher I was very intrigued by this phenomenon and started exploring it. It turned out to be a part of a very large and interesting field of linguistics, within which researchers have been studying code-switching, interlanguage, heritage language acquisition, second language acquisition, language attrition, language transfer, and more. I decided that I would like to be a part of that research process and study one particular phenomenon that I found very interesting and examples of which I encounter every day: negative transfer from English into Russian. This study would be impossible without my experience with Russian and English, so before introducing the study, I begin by describing my background. 


\subsection{My background}

I am an educated native speaker of Russian. I was born in Russia, grew up there and received a university degree in pedagogy and foreign languages in a Russian university. I also consider myself a bilingual; I might still not have a native-like proficiency in English, but I have been living in the U.S. for over three years now, and I am finishing my Master's degree in an American university, which requires a good command of English.

During my first year in the United States I was a Fulbright scholar and my job was to teach Russian to American students. All of them were second language learners (SLLs), which allowed me to better understand the specifics of teaching and learning Russian as a second language. Then, during my first year at Portland State University I taught Russian to a group that consisted only of heritage language learners (HLLs). It was my first experience with HLLs and it further raised my awareness of language acquisition (for example, that native-like pronunciation is not necessarily a sign of high proficiency).

In the last three years I have been teaching Russian to a mixed group; in PSU's Russian Flagship Program second language learners and heritage students were placed together based on their overall proficiency at the Intermediate High - Advanced ${ }^{1}$ levels. It is certainly true that these two groups of learners often have different needs, and it is very challenging to work with a mixed group. However, I strongly believe (and my experience supports) that it is not only possible to have SLLs and HLLs in one group, but it can be beneficial for both types of learners. Working with these two groups in one class

\footnotetext{
${ }^{1}$ Intermediate High-Advanced refers to ACTFL scale.
} 
made me want to investigate their acquisition of Russian and determine whether being English-dominant plays a role in it, thus leading to this study.

\subsection{My study}

The main purpose of my study was to explore the phenomenon of negative transfer from English in the writing of proficient heritage vs. second language learners of Russian.

There have been a number of studies of the acquisition of Russian as a second language (Gor et al., 2009; Hasko, 2009; Rifkin, 1995; Rosengrant, 1987; Thompson, 1997) as well as a heritage language (Andrews, 2001; Isurin \& Ivanova-Sullivan, 2008; Kagan, 2001; Kagan \& Dillon, 2001; Polinsky, 2000; Polinsky, 2008; Polinsky \& Kagan, 2007; Romanova, 2008). These studies showed that heritage and second language learners of Russian, having very different backgrounds, often make errors in the same categories (word order, tense and aspect, case errors). However, there are few studies that specifically compare the performance of heritage learners of Russian with second language learners (Isurin 2005; Friedman \& Kagan 2008; Gor et al 2009; Gor \& Cook 2010). Thus, it is an area in need of further research.

English-Russian transfer has been studied by several scholars (Pavlenko and Jarvis, 2002; Isurin, 2005; Marian and Kaushanskaya, 2007). Transfer errors have been identified and combined into different categories depending on the researcher's approach. These studies certainly contributed to the field of research of transfer in the production of Russian, but a lot is still left for future research. First of all, the studies listed above all 
looked at the language production by the students for whom Russian was the first language, the heritage speakers. Studying the negative transfer in second language learners of Russian and then comparing the results between the two groups of learners is, therefore, an area in need of more research.

Examining research literature, I found out that a number of studies have examined negative transfer from English into Russian, and other studies have compared the performance of heritage language learners (HLLs) to second language learners (SLLs), but little research has investigated the phenomenon of negative transfer in the writing of both HLLs and SLLs and compared the two groups. Thus, I decided to employ an exploratory approach and empirically investigate the differences in language transfer between these two groups of learners.

This research was conducted at the Russian Flagship Program at Portland State University. The RFP is an innovative undergraduate language program that allows students to achieve a professional level of proficiency in Russian while majoring in any discipline. In the RFP the study of the language is integrated into the university's general education program. Currently the program consists of an Introductory Track, an intensive program for students with little or no prior training in Russian, and an Advanced Track, for students at the intermediate to advanced level of proficiency. The program accommodates students from different backgrounds, from traditional second language learners to heritage learners. As an instructor, I know that both types of learners make errors, some of which are caused by negative transfer from English. I am interested in 
improving my students' writing, and I believe that identifying errors caused by negative transfer from English can help me address those errors better. 


\section{CHAPTER 2}

\section{LITERATURE REVIEW}

In this chapter, I provide a review of the research literature relevant to this study of English-Russian language transfer. The chapter is divided into four major sections. In the first section, I cover the concepts of language transfer and transfer errors. The second section looks at studies that approached transfer as a uni- or bidirectional process and identified categories of transfer errors. In the third section I describe second language learners of Russian and their main deficiencies. Heritage learners of Russian and their main deficiencies are the focus of the fourth section. I conclude the chapter with research questions for my study.

\subsection{Language transfer}

This section introduces the notion of negative transfer. Simply put, language transfer means using structures from one language when speaking or writing in another. Marian \& Kaushanskaya define transfer as "use of semantic or syntactic structures from the other language without active switching to that language" (2007, p. 369). For a language teacher it is very important to be aware of the phenomenon of language transfer. It shows teachers that students' linguistic background influences their second language proficiency, and it can possibly help to predict what areas might be particularly challenging for SL learners (Odlin, 1989).

In the literature, language transfer is usually divided into two categories: positive transfer that results in correct utterances and facilitates learning, and negative transfer 
(also known as interference) with incorrect outcomes (Gass \& Selinker, 2008). Because positive transfer results in correct utterances, its influence is difficult to identify. As Odlin notes, "the effects of positive transfer are only determinable through comparisons of the success of groups with different native languages" $(1989$, p. 36). Since positive transfer promotes the acquisition of the target language and is also more difficult to recognize, focusing on negative transfer is more relevant to my pedagogical goals of identifying problematic areas in language learning and looking for ways to target those challenges more efficiently. Thus, in my study I focus on negative transfer.

\subsubsection{Transfer Errors}

Negative transfer results in deviations from the target language. Odlin (1989) identifies four types of divergences that can be caused by differences between native and target languages: underproduction (or avoidance), overproduction, misinterpretation, and production errors. According to Odlin, three types of production errors are particularly plausible in the situation of cross-linguistic influence: substitutions (use of native language forms in the target language), calques, and alterations of structures. Alterations - for example, hypercorrections - sometimes go so far that they do not resemble the learner's native language and do not reflect any direct language influence. On the contrary, substitutions and calques clearly reveal the correspondence between learner's L1 and L2, and therefore, they are the types of errors often referred to as transfer errors (Odlin, 1989). 
However, there are more to transfer errors than just calques and substitutions, especially at the more advanced levels of language proficiency. For example, Broselow (1992) defines transfer errors the following way:

"Where the errors of language learners conform to the predictions made by the rules of the native language, even in environments not found in the native language, we can conclude that these errors result from transfer of the native language rules" (Broselow, 1992, p. 71).

Thus, transfer errors may include errors in word order, lexical borrowing, semantic extension, loan translation and more.

The notion of language transfer errors has been widely discussed, and numerous specific languages have been investigated by previous researchers (e.g. German by Hopp, 2009; Japanese by Kubota, 1998; Greek by Argyri \& Sorace, 2007; Farsi by Pajoohesh, 2007). However, there are still areas that need further research. Specifically several scholars (Hasko, 2009; Rifkin, 1995; Gor et al., 2009) have noted that the field of acquisition of Russian as a second language is "under-researched" (Hasko, 2009, p. 360) and specific SL Russian transfer errors are yet to be studied thoroughly.

\subsection{Transfer studies of Russian}

\subsubsection{Bidirectional transfer}

It has been argued in the literature that transfer is not a unidirectional influence, but rather, it is often bidirectional and influences a person's first and second languages (Pavlenko and Jarvis, 2002; Isurin, 2005; Marian and Kaushanskaya, 2007). 
One study on bidirectional Russian-English transfer was conducted by Pavlenko and Jarvis (2002). The researchers discussed the factors that potentially influence the amount of transfer. The study focused on nine categories of transfer, based on the contrastive analysis of the two languages in question as well as on previous research with Russian L2 users of English. A brief description of those categories is presented in Table 2.1 below. To summarize, in their study of elicited oral narratives of adult speakers (L1 Russian, L2 English), Pavlenko and Jarvis documented linguistic transfer in participants' L1 and L2. They identified 9 total error types, three of which apply to Russian-to-English transfer, the others to English-to-Russian transfer.

Table 2.1 Categories of bidirectional Russian-English transfer in adult Russian users of English (based on Pavlenko and Jarvis, 2002).

\begin{tabular}{|l|l|}
\hline Category & Definition/ explanation \\
\hline 1. Framing transfer. & $\begin{array}{l}\text { Choice of a linguistic frame to express a mental } \\
\text { representation. } \\
\text { For example, in English emotions are expressed with } \\
\text { adjectives as passive states; in Russian they are expressed } \\
\text { with verbs as active processes. }\end{array}$ \\
\hline $\begin{array}{l}\text { 2. Semantic extension. } \\
\text { Negative transfer error related to word choice, when L2 } \\
\text { words are used in the meaning of their perceived equivalent in } \\
\text { L1. } \\
\text { For example, fotoapparat - kamera. }\end{array}$ \\
\hline $\begin{array}{l}\text { The use of a phonologically, morphologically and/or } \\
\text { orthographically adapted word from one language in the } \\
\text { other. } \\
\text { Note: Lexical borrowing often occurs when a semantic } \\
\text { equivalent is perceived to be nonexistent in the target } \\
\text { language. }\end{array}$ \\
\hline $\begin{array}{l}\text { use of tense and aspect } \\
\text { inflections with verbs. } \\
\text { use of nominal case } \\
\text { inflections with nouns } \\
\text { and pronouns. }\end{array}$ & $\begin{array}{l}\text { Influence of the Russian aspectual system on tense markers in } \\
\text { English. } \\
\text { (From Russian to English only.) }\end{array}$ \\
\hline
\end{tabular}




\begin{tabular}{|l|l|}
\hline 6. Loan translations. & $\begin{array}{l}\text { Literal translations of compound words, idioms, and lexical } \\
\text { collocations from another language. }\end{array}$ \\
\hline $\begin{array}{l}\text { 7. Subcategorization } \\
\text { transfer. }\end{array}$ & $\begin{array}{l}\text { Transfer related to “the functional categories that verbs and } \\
\text { adjectives subcategorize for" (Pavlenko and Jarvis, 2002, p. } \\
\text { 203). } \\
\text { (From Russian to English only.) }\end{array}$ \\
\hline $\begin{array}{l}\text { 8. Transfer related to } \\
\text { article use. }\end{array}$ & $\begin{array}{l}\text { Unidirectional transfer from Russian into English, when lack } \\
\text { of articles in Russian leads to learners' omitting articles in } \\
\text { English. } \\
\text { (From Russian to English only.) }\end{array}$ \\
\hline 9. Word order transfer. & $\begin{array}{l}\text { Relying on the word order rules of one language while using } \\
\text { another language. }\end{array}$ \\
\hline
\end{tabular}

Additional research on cross linguistic Russian-English transfer added to the study by Pavlenko and Jarvis by focusing on one specific error category, word order. Isurin (2005) investigated the word-order transfer in a case study on Russian L1 forgetting and a cross-sectional study on L1 forgetting/ L2 acquisition. The results of the two studies suggested that "the mechanism of language transfer in L1 forgetting and L2 acquisition may indeed work in a similar way, that is irregularities in the target language may get replaced by a less marked structure from L2/L1 respectively" (p. 1127).

Another study in the field of language transfer for Russian-English was conducted by Marian and Kaushanskaya (2007). The study examined the processes of crosslinguistic transfer and borrowings in Russian-English bilingual language production. The study showed that more transfers were found for verbs than for nouns, and that concrete nouns and verbs were transferred more than abstract ones. The research was based on learners' oral production (autobiographical narratives that were tape-recorded, transcribed and analyzed). 
In sum, Russian-English transfer has been studied as a bidirectional process by several scholars (Pavlenko and Jarvis, 2002; Isurin, 2005; Marian and Kaushanskaya, 2007). Transfer errors have been identified and combined into different categories depending on the researcher's approach.

\subsubsection{L2 influence on L1}

A different approach to examining language transfer was employed by Pavlenko (2000), who brought together several studies in the area of L2 influence on L1 in adulthood, reconceptualized the findings and proposed a unitary theoretical framework. In the framework, Pavlenko suggested that language transfer (L2 $\rightarrow$ L1) results in five specific phenomena, as presented in Table 2.2 below.

Table 2.2 L2 influence on L1 (based on Pavlenko, 2000).

\begin{tabular}{|l|l|}
\hline Category & Description \\
\hline 1. Borrowing transfer. & Adding L2 elements to L1 (e.g., lexical borrowing). \\
\hline 2. Convergence. & $\begin{array}{l}\text { Creating a unitary system, distinct from both L1 and L2 (e.g., } \\
\text { production of consonants that are situated at the midpoint } \\
\text { between L1 and L2. }\end{array}$ \\
\hline 3. Shift. & $\begin{array}{l}\text { Moving away from L1 structures to approximate L2 structures } \\
\text { (e.g., semantic extension). }\end{array}$ \\
\hline $\begin{array}{l}\text { 4. Restructuring } \\
\text { transfer. }\end{array}$ & $\begin{array}{l}\text { Incorporating L2 elements into L1 that results in changes or } \\
\text { substitutions (e.g., when L2 rules are incorporated into L1 } \\
\text { grammar). }\end{array}$ \\
\hline 5. L1 attrition. & $\begin{array}{l}\text { Loss of L1 elements due to L2 influence (e.g., accepting } \\
\text { syntactically deviant L1 sentences under the influence of L2 } \\
\text { constraints). }\end{array}$ \\
\hline
\end{tabular}

In summary, Pavlenko suggested that L2 influences L1 on all levels: phonology, morphosyntax, lexis, semantics, pragmatics, and rhetoric. Documenting and 
understanding this influence may be, according to Pavlenko, "as important for the study of language development as to understand the functioning of L1 transfer" (2000, p. 200). However, I did not investigate L2 $\rightarrow \mathrm{L} 1$ transfer. In my study I focused on one direction of the transfer, from English to Russian, because my research had been inspired by my teaching experience, and for my pedagogical goals the influence of Russian on English is not relevant.

The studies by Pavlenko (2000), Pavlenko and Jarvis (2002), Isurin (2005), Marian and Kaushanskaya (2006) certainly contribute to the field of research of transfer in the production of Russian, but a lot is still left for future research. First of all, the studies discussed above all looked at the language production by the students for whom Russian was the first language, the heritage speakers. Studying the negative transfer in second language learners of Russian and then comparing the results between the two groups of learners is, therefore, an area in need of more research.

Thus, one of the goals of my study was to compare the performance of those two groups, SLLs and HLLs of Russian, with respect to transfer errors. In the next two sections I provide a description of each group and their main deficiencies as described in the literature.

\subsection{Second Language Learners of Russian}

Russian is one of the six official languages of the United Nations. Russian serves as a lingua franca in all former Soviet Republics and many Eastern European countries. Russian is considered "important to the future of the United States" 
(http://www.thelanguageflagship.org/funding/overview). Russian is a language known for many world-famous literary masterpieces. These are just a few reasons that motivate American students to learn Russian. However, the process of learning Russian is challenging, and significant linguistic and cultural differences make Russian a difficult language to acquire for native speakers of English. For instance, the grammatical system of the Russian language is generally very difficult to master for native speakers of English because of its extensive morphology, and verbs of motion are reported to be one of the main challenges (Hasko, 2009; Gor et al, 2009). Besides errors in production of verbs of motion, learners of Russian usually make errors in case and gender, in voice, conjugation, aspect and tense (Rifkin, 1995).

\subsubsection{Main deficiencies of Russian L2 learners}

Several studies have attempted to identify the errors that second language learners of Russian make (Thompson 1977; Rivlina 2005; Rosengrant 1987; Rifkin 1995). The errors include deviations in the following categories/ areas:

1) Word order. In English the order of the words in a sentence marks grammatical relations and, therefore, is relatively fixed. In contrast, in Russian the grammatical relations are expressed with the help of morphological markers, which allows for a relatively free word order (Thompson, 1977). This discrepancy often causes errors in production of Russian by American learners. For instance, in her comparative study on the Russian word order, Thompson (1977) provides the following example:

Я очень рад, что музыка играет. 
Ya ochen' rad, chto muzyka igrayet.

I very glad, that music is playing.

I'm very glad that the music is playing.

(Preferred word order for this context: Я очень рад, что играет музыка.)

Ya ochen' rad, chto igrayet muzyka.

I very glad that is playing music.

In Russian, subject-verb inversion is often required for a neutral sentence, and lack of inversion may result in an emphasis inappropriate for the given context. In English, such inversion is very uncommon, so English speakers tend to keep the "straight order" when using Russian (Thompson, 1977).

2) Graphics and punctuation. In English, every meaningful word in a title of a text is capitalized, and even advanced learners of Russian tend to transfer this habit into their writing in Russian, where only the first letter should be capitalized (Rivlina, 2005). Russian also does not capitalize words describing national identity.

3) Case. The case system in the Russian language is very complex. There are six cases, and pronouns, nouns, adjectives and numerals have to be inflected for case. Therefore, case errors are one of the most frequent errors English speakers make when writing in Russian (Rosengrant, 1987). Examples include the following:

а) Я вам слушаю. (Dative instead of accusative case. Correct: Я $\underline{\text { вас }}$ слушаю.) Ya vam slushayu. (Correct: Ya vas slushayu.)

I to you listen.

I am listening to you. (Rosengrant, 1987) 
b) Мои родители хотят, чтобы я стал професcopa. (Genitive instead of instrumental case. Correct: $<\ldots>$ npoфeccopom.)

Moi roditely khotyat, chtoby ya stal professora. $($ Correct: $<\ldots>$ professorom

My parents want that I became professor.

My parents want me to become a professor. (Rifkin, 1995)

4) Gender. There are three genders in Russian: masculine, feminine and neuter. Adjectives, pronouns, and verbs in the past tense need to agree with noun genders.

Мой (masc.) сестра (fem.) учится в Нью-Йорке. (Correct: Moя сестра учится в Нью-Йорке.)

Moy sestra uchitsya v new-yorke. (Correct: Moya sestra $<\ldots>$ )

My sister studies in New York. (Rifkin, 1995)

5) Aspect. As Rifkin (1995) explains, the choices of verbal aspect (perfective or imperfective) "depend entirely on the speaker's perspective on the event described" (p. 480). Verbal aspect is generally considered one of the most difficult parts of Russian grammar.

Я буду оканчивать университет через два года. (Imperfective instead of perfective.)

Ya budu okanchivat' universitet cherez dva goda.

I will be graduate university in two years.

I will graduate from the university in two years. (Rifkin, 1995)

6) Reflexive verbs. Generally, a reflexive verb is a verb with the same agent and patient. In a sentence with a reflexive verb in Russian, the agent is stated as a subject, and a 
reflexive suffix -ся (-sya) at the end of a verb indicates that the patient, although not explicitly stated, is the same as subject. Using a verb without the required reflexive suffix is a common error:

Я готовлю к экзамену. (Correct: Я готовлюсь $к$ экзамену.)

Ya gotovlyu k ekzamenu. (Correct: Ya gotovlyus' $k$ ekzamenu.)

I am preparing for an exam. (Correct: I am preparing myself for an exam.) (Rifkin, 1995)

7) Tense. There are three tenses in Russian (present, past, and future). One of the typical errors is using future tense in utterances with chtoby (in order to). As Rifkin explains, clauses with chtoby express indirect imperative and require past form (1995).

Мои родители хотят, чтобы я стану профессором. (Future tense instead of the required past. Correct: Мои родители хотят, чтобы я стал профессором.)

Moi roditeli hotyat, chtoby ya stanu professorom. (Correct: Moi roditeli hotyat, chtoby ya stal professorom.)

My parents want that I will become professor.

My parents want me to become a professor. (Rifkin, 1995)

8) Conjugation. In Russian a verb always changes to agree with a person it is referring to. The verb endings also depend on a conjugation group:

Они ходут на занятия. (First conjugation group ending instead of Second conjugation group ending. Correct: Они ходят на занятия.)

Oni hodut na zanyatiya. (Correct: Oni hodyat na zanyatiya.)

They go to classes. (Rosengrant, 1987) 
9) Negation. Russian is a language that allows negative concord. As Brown (2005) explains, negative concord refers to the phenomenon of "multiple negative constituents co-occurring which expresses only one semantic instance of negation" (p. 3). Unlike Russian, Standard English lacks negative concord and double negatives cancel one another, which results in a semantically positive sentence. Thus, it is difficult for native English speakers to acquire a habit of using multiple negatives in Russian.

\section{Example:}

Он нигде работает.

On nigde rabotayet.

He nowhere works.

He works nowhere.

Correct: Он нигде не работает.

On nigde ne rabotayet.

He nowhere not work.

In sum, Russian is known as a challenging language for native speakers of English. Acquisition of Russian as a second language has been widely studied and areas of potential errors have been identified (Brown, 2005; Hasko, 2009; Gor et al, 2009; Thompson 1977; Rifkin 1995; Rivlina 2005; Rosengrant 1987). L2 learners of Russian are known to make errors in case and gender, conjugation, word order, voice, aspect, tense, negation. These errors may be caused by different factors, one of which, negative transfer from English, is the focus of this study. 


\subsection{Heritage Learners of Russian}

Russian is known to be one of the most difficult languages to learn for a native speaker of English and, therefore, only a small number of students reach the high levels of proficiency necessary to function on a professional level (Kagan \& Dillon, 2001; Hasko, 2009). However, Russian is one of the critical languages in the U.S., important for national security, and the need for highly proficient speakers is growing. In this situation, as some researchers point out, heritage language learners "can fill the national need" (Kagan \& Dillon, 2001, p. 507).

The term heritage language learner has been defined in various ways, which reflects the complexity of the phenomenon. One of the most widely used definitions is the one suggested by Valdés (2000):

$<$ Heritage learner is $>$ a student who is raised in a home where a nonEnglish language is spoken, who speaks or merely understands the heritage language, and who is to some degree bilingual in English and the heritage language (p. 1).

In contrast, Polinsky offers a definition of the heritage language, not the speaker, and focuses on the order of language acquisition, which Valdés does not address. "By heritage language I mean a language which was first for an individual with respect to the order of acquisition but has not been completely acquired because of the switch to another dominant language" (Polinsky, as cited in Kagan \& Dillon, 2006, p. 86). Gass and Selinker (2008) also explain, "Heritage learners often do not become bilingual speakers because they do not continue to speak the heritage language as much as they 
speak the language of the non-home environment" (p. 24).

When defining a heritage learner of Russian, some researchers mention the importance of the formal education those learners received in their native countries: At the beginning of the twenty-first century in the United States, Russian heritage learners are the children of the third, fourth and later waves of immigration whose level of competency in Russian is directly tied to the amount of education they received in the former Soviet Union (Kagan \& Dillon, 2006, p. 87).

Using the amount of education received in Russian as the main criterion, Polinsky and Kagan (2007) divide Russian heritage speakers into three major groups. Group 1 includes those who finished high school in Russia or another former Soviet republic. Group 2 consists of those who had 6-7 years of school before their education was interrupted by immigration to the U.S. Group 3 is divided into 2 subgroups: (a) those who attended an elementary school in Russian, and (b) those who immigrated as preschoolers or were born in the United States into Russian-speaking households. If we place speakers of those groups on a continuum of proficiency in the language, with the native speakers being at one end, Group 1 would be closest to that end. Members of this group have the highest control of grammar, wide, almost native-like range of vocabulary, high speech rate, and "inside familiarity" with Russian culture (p. 385). On the other hand, members of Group 3 would be placed on the opposite end of the continuum: since they were educated primarily in English, their proficiency in Russian is significantly lower than that of two other groups. Polinsky characterizes these speakers as "incomplete 
acquirers" or "forgetters" (Polinsky, 2000).

The previous descriptions of heritage language speakers can be summarized into a description that fits the students that I work with. Thus, my working definition is the following:

A heritage language learner is a person who has been raised in a home where a language other than the dominant one is spoken, at least some of the time, and who can speak and understand it, while having native or native-like fluency in the dominant language of the society. The heritage language was the first language for the speaker in terms of order of acquisition; but the process of acquisition and mastering was interrupted at some point, and the second language was acquired and became dominant.

\subsubsection{Main deficiencies of heritage learners of Russian}

Although studies on HLLs of Russian are of interest, they do not specifically address the errors caused by negative transfer from English. However, they provide important background information about the heritage learners and offer insights into the areas of the language especially challenging for HLLs. For heritage speakers their L1 is subject to attrition and some of the deficiencies in the language of HLLs are caused by English becoming their dominant language and, therefore, by negative transfer.

Many researchers have attempted to identify heritage learners' deviations from standard Russian (Andrews, 2001; Isurin \& Ivanova-Sullivan, 2008; Kagan, 2001; Polinsky \& Kagan, 2007; Polinsky, 2008; Romanova, 2008). The most important 
findings include deviations in the following categories:

1) Tense and aspect. Inconsistent use of tense and aspect that is uncharacteristic of standard Russian (Polinsky, 2008b; Isurin \& Ivanova-Sullivan, 2008):

Потом мальчик одевается и собака назад на берегу пришла. (Correct: Потом мальчик оделся....)

Potom malchik odevayetsa i sobaka nazad na beregu prishla. (Correct: Potom malchik odelsya...)

Then boy dressing and dog back on shore came.

Then the boy is getting dressed and the dog came back to the shore. (Isurin \& Ivanova-Sullivan, 2008, p. 75) (Correct: Then the boy got dressed...)

2) Case errors. There are six cases in standard Russian. However, heritage speakers seldom use all of them. As Polinsky (2008b) reports, “American Russian essentially uses two cases: the unmarked case, which corresponds to the nominative in Full Russian, and the secondary object case, which corresponds to the accusative in Full Russian"(p. 158):

И мальчик идёт искать лягушка. (Unmarked instead of accusative case. Correct: И мальчик идёт искать лягушку. )

I malchik idyot iskat' lyagushka. (Correct: I malchik idiot iskat' lyagushku.) And boy goes look for frog. And the boy went looking for the frog.

3) Gender agreement. Polinsky (2008a) showed that although gender assignment does not disappear completely, it undergoes considerable changes in the language of heritage speakers, her category of "incomplete acquirers": 
Машина был большое. (Correct: Машина была больщая.)

Mashina byl bolshoye. (Correct: Mashina byla bolshaya.)

Car (fem) was (masc.) big (neuter)

The car was big. (Polinsky, 2008a, p.46)

4) Word order. Although the subject-verb word order is generally more frequent in standard Russian, verb-subject order is preferable for narratives and story-telling (Isurin \& Ivanova-Sullivan, 2008, p. 84). Heritage speakers, however, tend to use more subjectverb word order even in narratives. Here is an example of preferred verb-subject order:

Сидит возле реки маленький мальчик.

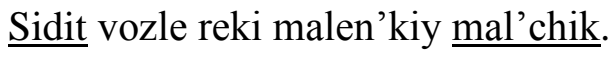

$\underline{\text { Sitting by river little boy. }}$

A little boy is sitting by the river.

5) Length of utterances. Research on heritage language narratives conducted by Polinsky (2008b) showed that HLLs use much shorter utterances and fewer embedded clauses than native speakers.

6) Speaking rate. As Polinsky reports, heritage speakers' rate is usually slower than the rate of native speakers due to problems with lexical access and retrieval (Polinsky, 2008b, p. 152).

Most of the examples above were taken from the study on heritage language narratives conducted by Polinsky (2008b). She examined the structure of heritage speakers' narratives and compared them to the narratives produced by "fully competent speakers" (p. 149). Polinsky described the competent speakers as speakers who have full 
control of the grammar and of styles and registers in their language. The subjects of the study were two heritage speakers of Russian, and the control group consisted of two full, native speakers. The narratives were elicited with the help of the so-called frog story (Berman \& Slobin, 1994). Comparing the HLLs to the NSs, Polinsky came to a conclusion that heritage speakers "clearly lag behind full speakers on every quantitative measure examined" (2008b, p. 158). Thus, HLLs like SLLs struggle on their way to high language proficiency and fall behind when compared to native speakers.

As seen from the previous two sections, heritage and second language learners of Russian, having very different backgrounds, often make errors in the same categories (word order, tense and aspect, case errors). Comparing these two groups of learners is a very interesting field of study. However, there are few studies that compare the performance of heritage learners of Russian with second language learners (Isurin 2005; Friedman \& Kagan 2008; Gor et al 2009; Gor \& Cook 2010). Isurin (2005) studied reverse (VS) word order in storytelling. The study showed that the percentage of cases with the reverse (VS) word order was almost the same for heritage learners and the native speakers of Russian (7\% for HLLs vs. $6 \%$ for NSs). However, for the second language learners the mean percentage of cases with VS order was much lower (only 1\%). Thus, the HLLs overall performed better than SLLs, the results consistent with the studies described below.

In their study, Friedman \& Kagan (2008) looked at academic writing proficiency of Russian heritage speakers and showed that they "used a relatively limited range of 
linguistic devices" in comparison to native speakers, but outperformed the secondlanguage learners of Russian (p. 196).

The study by Gor et al (2009) reported on experiments testing perception and production of verbs of motion by highly proficient American learners of Russian. The study showed that, first, neither the second language learners nor heritage learners of Russian attained native-like accuracy on processing verbs of motion; and second, heritage learners consistently surpassed L2 learners on all the tasks (Gor et al., 2009).

The study by Gor \& Cook (2010) contributed to the debates on the processing of verbal morphology. The research demonstrated that although heritage learners showed an advantage in verb generation and in the use of regular default pattern, L2 learners performed better "in the use of the cue-based complex morphological pattern" (Gor \& Cook, 2010, pp. 88-89).

This review has thus far showed that despite the extensive research on the acquisition as well as attrition of Russian, there is still a need for research that would investigate language transfer in the writing of heritage and second language learners of Russian.

\section{SUMMARY AND RESEARCH QUESTIONS}

The literature review established that the area of language transfer and transfer errors has been studied extensively in its relation to many different languages. The Russian-English cross-linguistic transfer has also been investigated by several scholars (Pavlenko \& Jarvis, 2002; Isurin, 2005; Marian \& Kaushanskaya, 2007). There have been 
numerous studies on L2 acquisition of Russian as well as on L1 forgetting of Russian. A number of studies have compared the performance of heritage language learners to second language learners. However, the area of language transfer in the production by both heritage and second language learners of Russian remains under-investigated.

One reason for the lack of heritage and second language comparisons is that it is rare for HLLs and SLLs to be placed together in a Russian language class. Some scholars believe that putting heritage and non-heritage learners together in one classroom is wrong. For example, Kagan and Dillon (2001) claim that at lower levels "to place heritage speakers together with students of Russian as a FL is to fail the needs of the former and to intimidate the latter" (p. 512). Since these two groups are usually taught separately, they are often studied separately. However, in the Advanced Track of PSU Russian Flagship classes, HLLs and SLLs are placed together. I thus had the rare chance to study them together and compare the two groups.

Since little research has investigated the phenomenon of negative transfer in the writing of both HLLs and SLLs and compared the two groups, this study employed an exploratory approach to empirically investigate the differences in language transfer between the two groups of learners. Specifically, the study addressed the following questions:

(1) What are the most common types of negative transfer from English that occur in the writing of students of Russian at the Intermediate High - Advanced levels of proficiency? 
(2) Are there differences in types and amount of negative transfer used by heritage learners of Russian vs. second language learners at comparable levels of proficiency? If so, what are the differences? 


\section{CHAPTER 3}

\section{METHODOLOGY}

Using an exploratory approach, this study empirically investigates the differences in language transfer between Russian SLL and HLL groups of learners. In this chapter, I begin by describing the context of the present study and its participants. I then offer a general outline of the methodology, providing information on the data collection, coding training and inter-rater reliability check procedures. I conclude with discussion of data analysis procedures.

\subsection{Context of the study}

This research was conducted at the Russian Flagship Program at Portland State University. The Language Flagship is an initiative of the National Security Education Program, which prepares American students to become global professionals with Superior $^{2}$ command of a language critical to US security. The Language Flagship is an innovative program of advanced language education, provided through a partnership among the federal government, educational institutions, and businesses (http://flagship.americancouncils.org/russian/).

PSU is one of four institutions offering a Russian Flagship Program. These programs aspire to produce Superior speakers of Russian, offering undergraduate students the "essential extended sequences of language courses and multiple entry points that will position them to pursue advanced subject-matter work in Russian" (Davidson,

\footnotetext{
${ }^{2}$ Superior refers to ACTFL scale.
} 
2009, p. 3). In other words, the Russian Flagship Program sets out to prepare highly proficient speakers of Russian.

PSU's Russian Flagship Program (RFP) was initiated in the summer of 2008. In the fall of 2008, the Freshman and Sophomore levels of the PSU RFP were successfully piloted. In the fall of 2009 another Russian across the curriculum course was added, Russian in the Major. This course provides students with an opportunity to develop a professional vocabulary and to become familiar with conventions of discourse in their chosen field. Currently the program consists of an Introductory Track, an intensive program for students with little or no prior training in Russian, and an Advanced Track, for students at the Intermediate to Advanced level of proficiency. In order to achieve professional proficiency in Russian, all Advanced Track students are required to take, first, a series of advanced language classes (like Advanced Russian grammar or phonology), second, Russian across the curriculum classes, taught in conjunction with a general education program, and third, content classes conducted in Russian. Students are also strongly advised to experience immersion living and study abroad.

\subsection{Participants}

Participants in this research were students of the Advanced Track of the RFP at PSU. The Advanced Track includes students from Russian-speaking backgrounds (heritage learners of Russian) and students who have learned Russian in a variety of academic and non-academic settings (predominantly, native speakers of English, hereafter called "second language learners of Russian"). 
In order to be admitted to the Advanced Track of the program, applicants need to demonstrate Intermediate High to Advanced proficiency in Russian (an ability to read, write and speak Russian well enough to participate in discussions of academic subjects of general interest). During the quarter of data collection for this research (Winter 2011), there were 13 students enrolled in the Advanced Track of the program, 7 second language learners (SLLs) and 6 heritage learners of Russian (HLLs).

To maintain participants' anonymity, I do not report demographic information about the participants and their language experiences, although I gathered this information. In chapter 4, I mention particular conditions that I think correspond to a learner making a particular error to the extent that I can without disclosing participants' identity.

The student participants were enrolled in three classes: On Democracy $\left(1^{\text {st }}\right.$ year $)$, Environmental Studies ( $2^{\text {nd }}$ year), and Russian in the Major ( $3^{\text {rd }}$ year). The classes were taught by three different instructors, including myself. In those three classes students were working on different types of assignments, focusing on narration and description $\left(1^{\text {st }}\right.$ year $)$, comparison and contrast $\left(2^{\text {nd }}\right.$ year $)$, or research skills ( $3^{\text {rd }}$ year). Transfer errors were not specifically addressed in those classes. There were two SLL and two HLL students taking two of the three classes $\left(2^{\text {nd }}\right.$ and $3^{\text {rd }}$ years $)$ at the same time. Students in their first year of the program were only taking an On Democracy class, taught by me.

I am an educated native speaker of Russian and a proficient speaker of English with more than six years of experience teaching both languages. By the beginning of my 
data collection, I had been teaching in the RFP at PSU for over two years. Thus, I was already familiar with the program, the course, and some of the student-participants.

\subsection{Data Collection}

I collected the written work of all RFP students of the Advanced Track (13 students) completed during the Winter quarter of 2011. This written work included students' paragraphs and essays, in-class writing samples, and answers to questions based on reading assignments.

All Advanced Track students were given writing assignments at least twice each week as a regular part of the course. Students were not asked to do any additional or special writing for my study. The number of papers depended on class assignments, but overall, I collected 101 papers of various types, length, and complexity.

All RFP students at PSU sign a general consent form, where they give permission to use their works for the purposes of research within the program. In addition, I also received the Human Subjects Research Review Committee permission to conduct my study, and had students sign a specific consent form for my particular research.

The RFP requires the students to submit electronic versions of their written works to their respective instructors. In order to collect the papers, I asked the students to email electronic copies of their work to their respective instructors as usual and had instructors then forward the copies to me. 
As I collected papers, I gave each student an individual number in order to make their work anonymous and, therefore, protect the identity of the student participants as well as to minimize my subjectivity when analyzing the students' writing.

\subsection{Coding Training}

In order to establish the reliability of the negative transfer identification, I asked a colleague to do a training and inter-rater reliability check. For the training we coded 15 essays and discussed differences in our negative transfer identification. The colleague (hereafter called "coder 2") is a native speaker of English and has years of experience with American students learning Russian. She has taught Russian continuously since 1972 and is the author of three Russian textbooks. Her perspective on negative transfer was especially useful not only because she could look at the errors from the perspective of a non-native speaker of Russian, but also provide insights as someone who has been teaching Russian grammar for years. Through the discussion, we gained a more principled analysis which could more reliably be applied.

In the training session, we agreed on 42 occurrences of negative transfer. There were 10 other errors on which we did not agree or felt uncertain. These 10 errors concerned comma use, inversion, and use of genitive case.

There were two types of comma use errors: omitting a comma before a conjunction/connector and inserting a comma after adverbial modifiers of place, time, frequency, etc. When we discussed those types of errors, coder 2 persuaded me that missing a comma was more likely a sign of students not knowing punctuation well in any 
language rather than negative transfer. We agreed, however, that inserting a comma after adverbial modifiers of place, time, frequency, etc. at the beginning of a sentence was indeed a negative transfer from English, for example:

Потом, начал движение...

Potom $_{2}$ nachal dvizheniye...

Later, it started moving...

In this example in Russian no comma is necessary after the first word.

Another type of error that I had originally marked as transfer and coder 2 did not was inversion:

Я получила зарплату первый раз и решила поехать в город...

Ya poluchila zarplatu pervyj raz i reshila poehat' $\mathrm{v}$ gorod...

I received salary first time and decided go to city.

I received my first salary and decided to go to the city.

Based on the context (and Russian theme-rheme rule), it would be better to put the words "first time" immediately after the subject:

Я первый раз получила зарплату <...>.

Ya pervyj raz poluchila zarplatu.

I first time received salary.

However, during the discussion session, coder 2 and I agreed that inversion of this type is not truly an error; Russian does allow a good amount of variation in terms of wordorder and a lot depends on what a writer is trying to emphasize. So we agreed that we should not mark lack of such inversion as negative transfer. 
Another error that I treated as negative transfer was the phrase «спрашивать вопросы», "to ask questions", where in the Russian variant both the verb and the noun have the same root, so it does not sound good to put these two words together (like "to present a present" in English, for example). Plus, the verb itself would be enough to express the same meaning and avoid redundancy. However, coder 2 persuaded me that we should not treat this type of error as negative transfer. I was convinced by her argument that this error is a borderline phenomenon: it is typical of English speakers learning Russian, but is not directly caused by interference from English. When there is one way to say something in English, and there are 5 ways to express the same idea in Russian, students tend to learn one Russian equivalent and use it in all contexts (while native speakers would use different variants for different contexts). Thus, having learned from the discussion with my co-coder I did not mark those types of errors as transfer.

There was only one occurrence that I did not identify as having an English influence, but coder 2 did:

Неужели не продала все свои джинсов? (Correct: все свои джинсы; accusative case, not genitive)

Neuzheli ne prodala vse svoi dzhinsov?

How come you didn't sell all of your jeans?

I only saw a case error there, but my colleague explained that this is most likely the student's equivalent of "all of your jeans" in English. In such phrases, students learn to use genitive, but it does not always apply in Russian. 
My colleague and I also agreed that for the sake of reliability of the research, errors that a coder could not identify as a clear occurrence of negative transfer should not be coded as transfer. That is, ambiguous occurrences were not classified as transfer.

In sum, having discussed the error coding process with a native speaker of English who has years of experience teaching Russian helped me gain a more principled analysis and improve the reliability of my coding.

\subsection{Inter-rater Reliability Check}

After the training session, in order to establish the reliability of the negative transfer identification, coder 2 and I met for an inter-rater reliability check. We coded 10 essays and agreed on $94.4 \%$ of the occurrences of negative transfer, with only one discrepancy. The coding therefore appeared acceptably reliable.

\subsection{Data Analysis}

After establishing the inter-rater reliability, I coded the written work for negative transfer from English. To do so I first identified and marked the errors that I considered to be negative transfer. Since it was impossible to tell if an error was a typo, I analyzed the texts as typed. In other words, if the way a word was typed was an error, I counted it as an error. After I identified all the occurrences of negative transfer, I then classified them into categories that emerged from the data. However, there was a lot of variation in the amount of writing contributed by each participant. So that no individual had a disproportionate effect on the results, it was important to norm the count per 1000 words 
for each student for each type of error. This allowed me to determine the most common occurrences of negative transfer in the data both for categories of errors and for total occurrences of errors.

I then proceeded to the second stage of my research, comparing the HLL group and the SLL group, and as part of the comparison I considered the individual variation in each group. Specifically, I sorted the occurrences of negative transfer into two groups, SLL and HLL. Next I calculated the mean for each group based on the normed count per 1000 words for each student. Then I compared the results in order to see if there was a difference in types and amount of negative transfer used by the students in two groups.

I had originally planned to run a test of statistical difference to see if the differences in categories of transfer errors between the SLL and HLL groups were significant. However, the study had an unexpectedly small number of participants and errors, resulting in the numbers being too low for statistical tests. Instead, I only described the nature and frequency of errors. Additionally, since so much variation existed in the data, I also discussed individual variation within each group. In the end, I provided a short description of outliers, participants who heavily affected the results.

In this chapter, I provided a detailed description of the data collection and analysis. The next chapter discusses the results of the analysis and interprets the findings. 


\section{CHAPTER 4}

\section{RESULTS AND DISCUSSION}

In this chapter I present the results of the data analysis, answering the research questions formulated in chapter 2. The first part of the chapter describes the quantitative analysis of the most common types of negative transfer from English found in the writing of students of Russian at the Intermediate High - Advanced levels. Thus, it answers the research question 1 . The second part of the chapter answers research question 2 , looking at the differences in types and amount of negative transfer used by HLLs vs. SLLs at comparable levels of proficiency. This part also provides a discussion of the individual variation within each group. Finally, a brief summary of the findings conclude the chapter.

\subsection{Overview of frequency analysis}

Overall, there were 101 papers submitted during the quarter of the data collection, 56 papers submitted by the SLLs and 45 by the HLLs. Despite a small sample of only 13 participants, 7 SLLs and 6 HLLs, there was a lot of variation in the amounts they contributed. The total number of words provided by the students was 18,421 . The SLLs contributed 9,610 words, and the HLLs 8,811 words. The average number of words per participant was 1417, but the individual variation in contribution varied greatly. Specifically, it ranged from the minimum of 206 words submitted by one student to the maximum of 3774 words provided by another. As explained in chapter 3, so that no 
individual influenced the analysis disproportionately, it was important to norm the counts per 1000 words for each student and then to calculate the mean for SLL and HLL groups.

\subsection{The most common types of negative transfer}

The number of transfer errors found in the data was low. None of the errors were more frequent than 5 per 1000 words. Altogether, 13 categories of errors emerged from the data. The frequencies for each category of errors are presented in the Table 4.1.

Table 4.1 Normed frequency of errors (per 1000 words).

\begin{tabular}{|l|l|l|l|}
\hline & Error Category & Frequency & Percentage \\
\hline 1. & semantic extension & 4.12 & 14.6 \\
\hline 2. & comma after introductory phrase & 3.76 & 13.3 \\
\hline 3. & lexical borrowing & 3.14 & 11.1 \\
\hline 4. & null subject errors & 3.13 & 11.1 \\
\hline 5. & reflexive possessive pronoun «свой/ svoj» (one 's own) & 2.48 & 8.8 \\
\hline 6. & capitalization & 2.07 & 7.3 \\
\hline 7. & loan translation & 1.86 & 6.6 \\
\hline 8. & prepositions & 1.81 & 6.4 \\
\hline 9. & conceptual shift & 1.68 & 5.9 \\
\hline 10. & «ecли/ли» - if/whether & 1.55 & 5.5 \\
\hline 11. & number (sing/pl) & 1.1 & 3.9 \\
\hline 12. & adjectives for nationality & 0.8 & 2.8 \\
\hline 13. & negation & 0.79 & 2.8 \\
\hline & & $28.29=$ & \\
& & $100 \%$ & \\
\hline
\end{tabular}

The first research question concerns the most common types of negative transfer overall in the writing of proficient students of Russian, regardless of the students' status as HLL or SLL. Figure 4.1 indicates, in pie-chart form, the breakdown of types of negative transfer for all participants. 
Figure 4.1 The most common types of negative transfer from English that occurred in the writing of students of Russian at the Intermediate High - Advanced levels (percentage).

\section{The most common types of negative transfer from English}

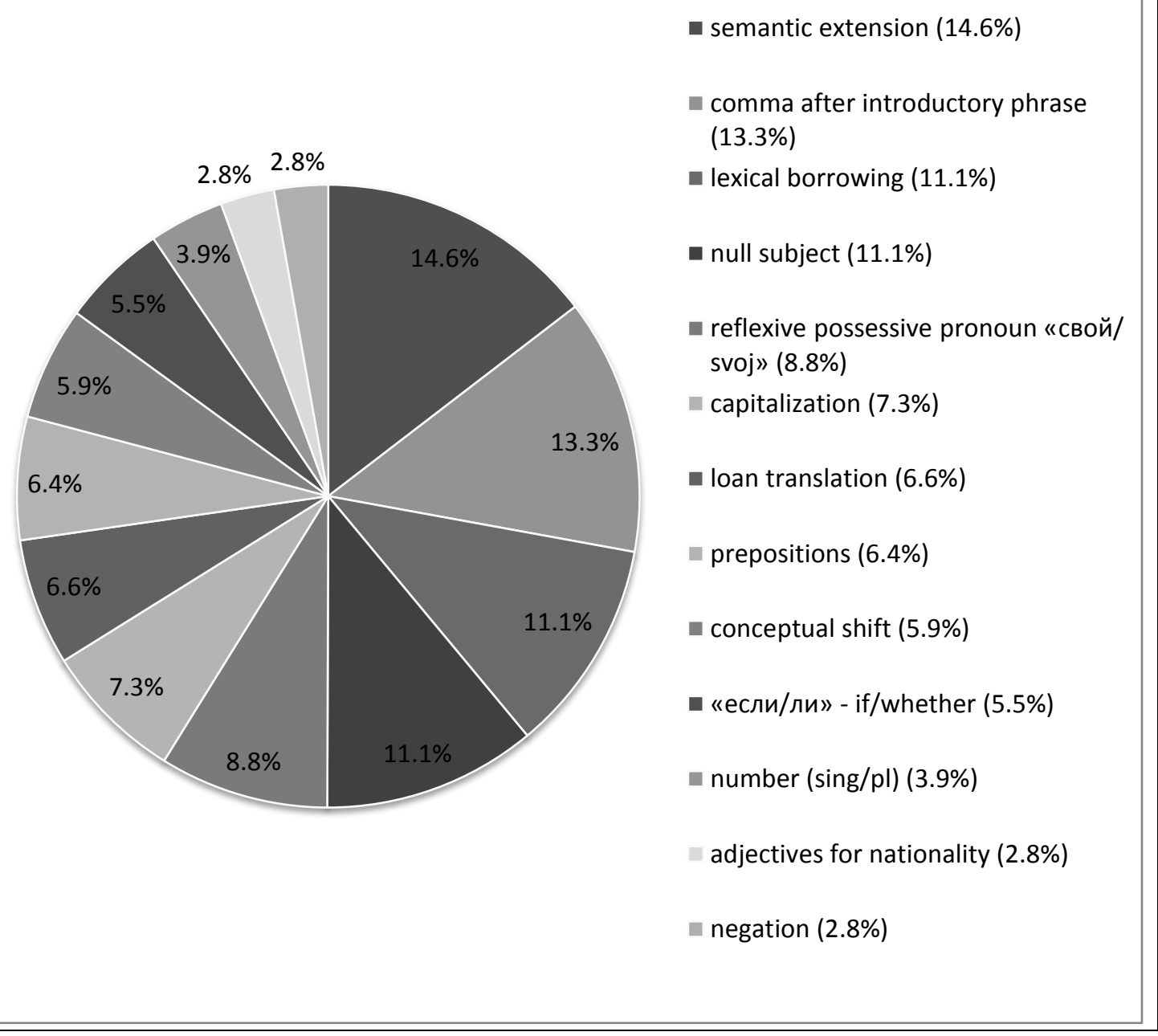

As illustrated by the chart, the most common categories overall were semantic extension, comma after an introductory phrase, lexical borrowings and the null subject errors. Each of these four categories with frequencies over 3 per 1000 words accounted 
for over $10 \%$ of the total number of errors. Together they accounted for about $1 / 2$ the errors.

The categories are discussed in detail below.

\subsubsection{Semantic extension}

As Figure 4.1 indicates, semantic extension was the most common type of negative transfer for the participants overall. The category of semantic extension constitutes $14.6 \%$ of the total number of mistakes overall, with a mean frequency of 4.1 per 1000 words.

As discussed in chapter 2, semantic extension is a negative transfer error related to word choice, when L2 words are used in the meaning of their perceived equivalent in the L1 (Pavlenko and Jarvis, 2002).

One common instance of semantic extension was using the word "человек" (chelovek, person). In English, the term "person" has a very broad semantic scope. In Russian, on the other hand, the use of the word "chelovek" is much more limited and, particularly, it is almost never used with national identity adjectives, as it was used by a student participant of this research:

Каждый египетский человек может... .

Kazhdyi yegipetskiy chelovek mozhet...

Every Egyptian person can...

Correct: Каждый египтянин может....

Kazhdyi yegiptyanin mozhet....

Every Egyptian can... . 
Unlike English where the same word can be used as both noun and adjective to describe national identity, Russian differentiates between adjectives and nouns in this category. It comes as no surprise then, that learners of Russian often resort to the formula nationality adjective + chelovek when referring to national or ethnic identity nouns: yegipetskiy chelovek instead of yegiptyanin (Egyptian person instead of an Egyptian), as seen in the example above.

Another example of a common semantic extension error was misuse of a word «публичный» (publichny, public). Even though "publichny" is a possible translation of the English word "public", it is used in limited contexts in Russian. The main meaning of the word "publichny" is "something that is done in public or done for the public". Thus, "publichny" in Russian cannot be used with a word such as "health", as it was used by one of the participants in my research:

охраны публичного здоровья

ohrany publichnogo zdorovya

protection of public health

Correct: охраньз здоровья населения

protection of the health of the population

Overall, there were 8 instances of semantic extension found in the data. Individual variation is discussed in part 2 of this chapter. 


\subsubsection{Comma after an introductory phrase}

The second most common type of negative transfer overall was a comma after an introductory phrase. Errors in this category account for $13.29 \%$ of all errors, with a frequency of 3.76 per 1000 words.

Putting a comma after an introductory phrase was an error I expected to find in

my data. Russian and American English punctuation rules differ significantly, which causes difficulties for both native English speakers learning Russian and for heritage speakers of Russian.

The English punctuation rules are not easy to state. According to The Longman Writer's Companion, readers usually expect a comma to signal where the introductory phrase ends and the main sentence starts (Anson, Schwegler, \& Muth, 1999). Hacker and Sommers (2011) provide the following explanation:

The most common introductory word groups are phrases and clauses functioning as adverbs. Such word groups usually tell when, where, how, why, or under what conditions the main action of the sentence occurred (p. 260).

In Russian the punctuation rules for the introductory phrases and words are different, and most of the introductory phrases separated by a comma in English should not be followed by a comma in Russian. Often, words that are considered introductory in English are viewed differently in Russian. Introductory (or transition) expressions in Russian are words and phrases that are not grammatically connected with a sentence. 
Usually, these words express a speaker's attitude toward or evaluation of the utterance, provide information about the source or show connection with a context. For example:

Вероятно, снег пойдёт не скоро.

It probably will not start snowing any time soon.

It is important to mention that both English and Russian use commas after introductory clauses; it is the introductory phrases where the rules are different in the two languages. Unlike in English, words that come before the main clause are not necessarily separated by a comma in Russian. Here is an example from Hacker and Sommers:

Near a small stream at the bottom of the canyon, the park rangers discovered an abandoned mine (p. 260, 2011).

Недалеко от ручья на дне каньона_смотрители парка обнаружили заброченную шахту.

Thus, students who write in English much more than in Russian may transfer the rules of English punctuation into their Russian writing. Specifically, they may use a comma to separate an introductory phrase (typically, a prepositional phrase) from the rest of the sentence. Some examples from the students in this study included:

1) Через несколько дней в Иране, ей приходится....

Cherez neskolko dney v Irane, yey prihoditsya...

After several days in Iran, she has to...

2) В настоящее время, большинство людей....

V nastoyasheye vremya, bolshinstvo lyudey....

Nowadays, most people... 
In these examples, learners used commas after introductory prepositional phrases "after several days" and "nowadays" which in Russian should not be followed by a comma.

Using a comma after an introductory phrase was the second most common case of negative transfer from English into Russian in the data I collected for this study.

\subsubsection{Lexical borrowings}

The third most common type of negative transfer from English found in my data overall was lexical borrowing. Errors in this category constitute $11.1 \%$ of all errors, with a frequency of 3.1 per 1000 words.

As discussed in chapter 2, the term "lexical borrowing" has a wide range of definitions, but for the purpose of this research, I chose the definition offered by Isurin: lexical borrowings are "L2 words in lieu of the existing L1 equivalents or to represent a concept that was either not lexicalized or not familiar to the speaker in the L1" (Isurin 2007, p.364).

In my data, the lexical borrowings category comprises mostly transliterated words, i.e. English words spelled with Russian letters. Since the data were collected from students' written homework, the array of strategies students could use was limited. For example, in an oral conversation with another Russian-English bilingual, a student could (and very likely would) resort to code-switching, while in written homework this option was unavailable. However, instead of appealing to circumlocution or looking up a word in a dictionary, some students turned to lexical borrowing. While it is understandable for partial cognates, like transportation and religion, it was interesting to see advanced 
students transliterating words like mobs (мобы), victimization (виктимизация), destination (дестинация), Jипior (Жунер). Investigating how students use borrowing as a strategy is beyond the scope of this paper, but it is a question worth investigating in future research.

\subsubsection{Null subject errors}

The fourth most common type of negative transfer overall was null subject errors. With a frequency of 3.1 per 1000 words, this category accounts for $11.1 \%$ of all transfer errors found in my data.

English expresses subjects obligatorily and does not usually allow subjectless sentences. The subject of a sentence can be non-existent but the reference to it is still required syntactically:

It is important to finish this exercise.

On the contrary, Russian may be considered a null-subject language i.e., a language whose grammar permits sentences with unexpressed subjects. If an independent clause lacks an explicit subject, this clause is considered to have a null subject. As a rule, a null subject language requires gender, person, and number agreement. According to Gordishevsky and Avrutin (2005), in discussion of null-subject languages, Russian presents a special interest. Russian has a rich morphological paradigm with obligatory subject-verb agreement. However, the system of distribution of overt and covert subjects is quite intricate, and omissions are allowed and even preferred in certain contexts, but not in others. These restrictions, however, do not come from the morphosyntax (as 
Gordishevsky and Avrutin point out), but depend on the context. Therefore, it is very difficult for learners of Russian to acquire this system. Under the influence of English, where use of subjects is abligatory, students of Russian tend to insert a subject even in those contexts where the subject should be omitted in Russian. In my data, one example of English interfering with the student's ability to correctly form subjectless (impersonal) sentences was:

Я поняла, что это было дешевле бродить по рынку... .

Ya ponyala, chto eto bylo deshevle brodit' po rynku... .

I realized that it was cheaper to wander around the market... .

Correct: Я поняла, чтоо было дешевле бродить по рынку... (No “это” is needed. It's a null-subject sentence.)

There were 12 examples of null subject error found in the data. The SLL - HLL specifics as well as the individual variation within each group are discussed in part 2 of this chapter.

\subsubsection{Reflexive possessive pronoun "svoj" (one's own)}

This was the fifth most common category of transfer errors overall. It accounts for $8.8 \%$ of the total number of errors, with a mean frequency of 2.5 per 1000 words. This category describes errors of using non-reflexive possessive pronouns instead of the required reflexive possessive pronoun «свой/ svoj» (one's own).

The possessive pronoun "svoj" (one's own) is not an easy concept to understand for a native English speaker. "Svoj" refers back to the subject of the sentence. It is used 
instead of the pronouns "my, your, his, her, our, their" in sentences where the possessives are not part of the subject. It is important to remember, however, that in sentences where the possessive is the subject or where reference to the subject cannot be established, the possessive "svoj" should not be used. In sum, the reflexive possessive pronoun "svoj" is used when the referent of the possessive is identical with that of the subject, e.g. Я взял свою книгу "I took my (own) book". It is important to note that the use of the pronoun "svoj" is optional for the first and second person subjects and required for the third person. See Table 4.2.

Table 4.2 Possessive Pronoun "svoj".

\begin{tabular}{|c|c|c|c|c|}
\hline & "svoj” & & no "svoj" & \\
\hline $\begin{array}{l}1^{\text {st }} \\
\text { person }\end{array}$ & $\begin{array}{l}\text { Я нашла мой/вой } \\
\text { ключ. } \\
\text { Ya nashla moj/svoj } \\
\text { kluch. } \\
\text { "Svoj" is optional. }\end{array}$ & $\begin{array}{l}\text { I found my } \\
\text { (own) key. }\end{array}$ & $\begin{array}{l}\text { Я не знаю, где } \\
\text { мой ключ. } \\
\text { Ya ne znayu, } \\
\text { gde moy kluch. }\end{array}$ & $\begin{array}{l}\text { I don't know } \\
\text { where my } \\
\text { key is. }\end{array}$ \\
\hline $\begin{array}{l}2^{\text {nd }} \\
\text { person }\end{array}$ & $\begin{array}{l}\text { Ты купил твоей/своей } \\
\text { дочке подарок? } \\
\text { Ty kupil tvoyej/svojej } \\
\text { docheri podarok? } \\
\text { "Svoj" is optional. }\end{array}$ & $\begin{array}{l}\text { Have you } \\
\text { bought a gift } \\
\text { for your (own) } \\
\text { daughter? }\end{array}$ & $\begin{array}{l}\text { Твоей дочке } 3 \\
\text { года? } \\
\text { Tvoyej dochke } \\
\text { tri goda? }\end{array}$ & $\begin{array}{l}\text { Is your } \\
\text { daughter } 3 \\
\text { years old? }\end{array}$ \\
\hline $\begin{array}{l}3^{\text {rd }} \\
\text { person }\end{array}$ & $\begin{array}{l}\text { Он любит свою собаку. } \\
\text { On lubit svoju sobaku. } \\
\text { "Svoj" is obligatory. }\end{array}$ & $\begin{array}{l}\text { He likes his } \\
\text { (own) dog. }\end{array}$ & $\begin{array}{l}\text { Как зовут его } \\
\text { собаку? } \\
\text { Kak zovut ego } \\
\text { sobaku? }\end{array}$ & $\begin{array}{l}\text { What's his } \\
\text { dog's name? }\end{array}$ \\
\hline
\end{tabular}

The reflexive possessive pronoun "svoj" is a very frequent word. In fact, the lemma "свой" (i.e. "svoj" in all its grammatical forms) is the 27 th most frequently used word in the Russian National Corpus. The other possessive pronouns have considerably lower frequency: from "его"- his being the 37th most frequent word, to "твой" - your being the 254th (Comer, 2009, p. 80). 
In the examples below, learners used a non-reflexive possessive pronoun instead of the reflexive possessive pronoun «свой/ svoj» (one's own) required in Russian:

1) Жители страны были недовольны их правителем.

Zhiteli strany byli nedovolny $\underline{\mathrm{ih}}$ pravitelem.

Citizens of country were unsatisfied their leader.

Citizens were not satisfied with their leader.

Correct: Жители страны были недовольны своим правителем.

Zhiteli strany byli nedovolny svoim pravitelem.

Citizens were not satisfied with their (own) leader.

2) Он был арестован из-за его религии.

On byl arestovan iz-za ego religii.

He was arrested because of his religion.

Correct: Он был арестован из-за своей религии.

On byl arestovan iz-za svoyei religii.

He was arrested because of his (own) religion.

The subjects of my research were advanced students of Russian, but they still struggled with identifying contexts for obligatory use of the reflexive possessive pronoun. It is important to note that although there were not very many occurrences of this error found in the data, I know that in less polished writing as well as in speaking, this error is relatively frequent for students. And since errors of this type can often cause misunderstanding, they should be addressed by instructors, as discussed in chapter 5 . 


\subsubsection{Capitalization}

Capitalization was the sixth most frequent type of error. This category accounts for $7.3 \%$ of all errors, with a mean frequency of 2.1 per 1000 words. Starting the research, I expected to find this error in students' writing because I knew from my teaching experience how common this error was.

Like English, Russian capitalizes proper nouns. However, neither adjectives derived from proper nouns nor national identity nouns should be capitalized. See Table 4.3 .

Table 4.3 Capitalization in Russian.

\begin{tabular}{|l|l|l|l|}
\hline $\begin{array}{l}\text { Proper noun } \\
\text { country/ city) }\end{array}$ & $\begin{array}{l}\text { Nationality/ city } \\
\text { origin }\end{array}$ & Language & Adjective \\
\hline $\begin{array}{l}\text { Pocсия } \\
\text { Russia }\end{array}$ & $\begin{array}{l}\text { русский } \\
\text { (a) Russian }\end{array}$ & $\begin{array}{l}\text { русский } \\
\text { Russian }\end{array}$ & $\begin{array}{l}\text { русские песни } \\
\text { Russian songs }\end{array}$ \\
\hline $\begin{array}{l}\text { Америка (CШA) } \\
\text { America (the USA) }\end{array}$ & $\begin{array}{l}\text { американец } \\
\text { (an) American }\end{array}$ & $\begin{array}{l}\text { американский } \\
\text { английский } \\
\text { Аmerican English }\end{array}$ & $\begin{array}{l}\text { американские } \\
\text { фильмы } \\
\text { American movies }\end{array}$ \\
\hline $\begin{array}{l}\text { Mocква } \\
\text { Moscow }\end{array}$ & $\begin{array}{l}\text { москвич } \\
\text { (a) Mоscovite }\end{array}$ & $\begin{array}{l}\text { московский } \\
\text { диалект } \\
\text { Моsсоw dialect }\end{array}$ & $\begin{array}{l}\text { московское метро } \\
\text { Moscow subway }\end{array}$ \\
\hline $\begin{array}{l}\text { Париж } \\
\text { Рaris }\end{array}$ & $\begin{array}{l}\text { парижанин } \\
\text { (а) Рarisian }\end{array}$ & $\begin{array}{l}\text { парижский диалект } \\
\text { Рaris dialect }\end{array}$ & $\begin{array}{l}\text { парижская мода } \\
\text { Рaris fashion }\end{array}$ \\
\hline
\end{tabular}

From Table 4.3 we can see that in Russian the names of the countries are capitalized, while the nationalities derived from them are not (nor are the names of languages). The names of cities are capitalized, but the names of people originated from a city are not capitalized. 
In the first example below, a student capitalized an adjective (Russian) derived from a proper noun (Russia). However, in Russian such adjectives should not be capitalized:

1) или Русских танках

ili Russkih tankah

or Russian tanks

Correct: или русских танках

ili russkih tankah

2) С точки зрения экологии ㅆериканцы... .

S tochki zreniya ecologii Amerikantsy ....

From the ecological standpoint $\underline{\text { Americans... }}$

Correct: С точки зрения экологии аммериканиыь... .

S tochki zreniya ecologii amerikantsy ....

In the second example a student capitalized a noun used to describe national identity (American), another common mistake. Such nouns are not capitalized in Russian.

Capitalization errors are unlikely to cause misunderstanding in communication with native Russian speakers. However, at high levels of proficiency such errors can be considered "inappropriate"; since the rule is so straightforward, it should be mastered.

\subsubsection{Loan translations}

This was the seventh category. It accounts for $6.6 \%$ of all errors, with a frequency of 1.9 per 1000 words. As discussed in chapter 2, loan translations (i.e., calques) are 
literal translations of collocations, idiomatic expressions or compound words (Pavlenko \& Jarvis, 2002). Below is an example of loan translation from my data:

1) Музей является домом одному маятнику... .

Muzey yavlyaetsa domom odnomu mayatniku... .

Museum is a home to one pendulum... .

Correct: В музее хранится/ находится маятник... .

$V$ muzeye hranitsya/ nahoditsya mayatnik... .

In the museum there is a pendulum....

As is often the case with idiomatic expressions, English "to be a home to" sounds very awkward and unnatural if translated literally into Russian. This particular phrase (является домом - is a home to) was used by two different students who were taking two different classes taught by two different instructors.

Another example of loan translation in my data was the following:

2) Скорее или позднее каждый будет...

Skoreye ili pozdneye kazhdyi budet...

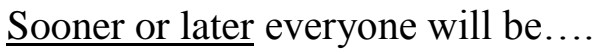

Correct: Рано или поздно каждый будет...

Rano ili pozdno kazhdyi budet...

Early or late everyone will be....

Interestingly, in a phrase where English uses comparative forms (sooner or later), Russian requires regular adverbs (рано или поздно - early or late). Thus, use of literal translation gets the meaning across, but clearly stands out as an incorrect expression. 


\subsubsection{Prepositions}

Errors in this, the eighth, category accounted for $6.4 \%$ of all errors, with a mean frequency of 1.8 per 1000 words. One example from my data was:

1) между людьми, говорящими определённый язык

mezhdu ludmi, govoryashimi opredelennyi yazyk

between people speaking a certain language

Correct: между людьми, говорящими на определённом языке

mezhdu ludmi, govoryashimi na opredelennom yazyke

between people, speaking on certain language

In English, the verb to speak does not require a preposition before a name of the language. In Russian, on the other hand, the preposition $н a(n a=o n)$ should be used when the verb to speak is followed by a noun phrase (adjective + the noun язык (yazyk $=$ language). Students at the upper levels of proficiency are usually aware of these differences. However, this student made this mistake three times in a single essay, so it was not a typo.

The category of preposition errors is, in my opinion, one of the most challenging both for instructors to address and for students to master. The list of words and phrases that require certain prepositions or no prepositions can appear endless. Exploring different strategies to prevent errors of this category is a very interesting and worthy topic for teachers and researchers. 


\subsubsection{Conceptual shift}

Errors in this category accounted for $5.9 \%$ of all errors, with a frequency of 1.7 per 1000 words. As discussed in chapter 2, conceptual shift errors are said to be characteristic of heritage speakers. Conceptual shift is often a result of the first language attrition that occurs when immigrants have been immersed in a target language community for a significant amount of time (Pavlenko, 2002). Pavlenko described the phenomenon of conceptual shift in examples of representations of emotions:

In English emotions are usually conceptualized as states caused by external and/or past causes, while in Russian experiences comparable to 'anger', 'happiness', or 'concern' are often conceptualized as inner activities in which one engages more or less voluntarily. (2002, p. 87)

This difference in mental representation corresponds to different linguistic framing. Specifically, as Pavlenko (2002) explains, English uses adjectives and pseudo-participles (e.g. she is upset), while in Russian emotions are commonly expressed with verbs (e.g. ona rasstroilas' 'she got upset') (p. 87).

As a result of these differences in mental representations and linguistic framing of emotions, heritage learners may experience a conceptual shift. Below is an example I found in the data. Instead of using a processual reflexive verb 'rasstroilsya' ('got sad'), the student resorted to a state verb, thus framing the emotion as a state rather than a process:

он стал ещё более грустный 
on stal yeschyo boleye grustnyj

he became even more sad

Correct: он расстроился ещеё больще

on rasstroilsya yeschyo bolshe

he got sad even more

As seen from the example, the student did not express the emotion as a process, which would be more appropriate in Russian. Instead, the emotion was expressed more as a state, a framing common in English.

\subsubsection{Conjunction "yesli/lii" (if/whether)}

The errors in this, tenth, category constituted $5.48 \%$ of all errors, with a frequency of 1.55 per 1000 words.

Russian has two conjunctions that can be translated as "if" in English. These conjunctions are "если/yesli" and "ли/li". The rule is straightforward: if in English you may use whether, in Russian you must use “ли/li”; otherwise, use “если/yesli”. Despite the clear rule, most learners of Russian tend to use "если/yesli" in both contexts. Part of the difficulty for them, I believe, is that clauses with "если/yesli" follow a direct, English-like, word order: subordinate conjunction + subject + verb, for example:

Я пойду на праздник, если он пригласит меня .

Ya poydu na prazdnik, yesli on priglasit menya .

I will go to party, if he will invite me.

I'll go to the party if he invites me. 
On the contrary, the subordinate clause introduced bу “ли/li" requires inverted word order. Unlike “если/yesli", the subordinate conjunction "ли/li" is a clitic, i.e., a morpheme that syntactically is a word, but phonologically is bound to another word. In other words, “ли/li" in Russian is a word that does not have an accent and should, therefore, be attached to a word that does have accent. For this reason, “ли/li” should never be in the first position in a clause like other conjunctions. In fact, the verb must be moved to the beginning of the clause and “ли/li" should be attached after the verb and before the subject:

Я не знаю, пригласит (Verb) 쓰 он (Subject) меня на праздник.

Ya ne znayu, priglasit li on menya na prazdnik.

I not know, will invite if he me to party.

I don't know if he will invite me to the party.

If a speaker is questioning not a verb, but a different word in a sentence, that word must be moved to the beginning of the clause:

Я не знаю, дома иㅡ мама.

Ya ne znayu, doma li mama.

I don't know, at home if mom.

I don't know if mom is home.

In the examples below, students used the conjunction "yesli" and a direct, English-like word order instead of resorting to the conjunction "li" and a required inversion in the second clause: 
1) спрашивали, если я в безопасности

sprashivali, yesli ya v bezopasnosti

they were asking if I was safe

Correct: спрашивали, в безопасности лия я

sprashivali, v bezopasnosti li $y a$

2) Можно быстро определить если человек находится... .

Mozhno bistro opredelit yesli chelovek (Subject) nahoditsa (Verb)... .

Possible quickly see if person is

You can quickly see if a person is... .

Cогrесt: Можно быстро определить, находится ли человек... .

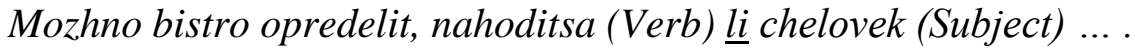

Even though this type of error was not the most frequent in the data, as an instructor of Russian I know that virtually all my students tend to use "если/yesli" for both if and whether, especially in their oral discourse. I was glad to see, however, that in fairly polished writing assignments students managed to use the appropriate conjunction more consistently.

\subsubsection{Number}

The errors in this category accounted for $3.9 \%$ of all errors, with a frequency of 1.1 per 1000 words. In my data, this category contains errors that use plural as in English, in contexts that require singular in Russian. Examples from the students in this study included the following: 
1) У многих людей нет работ.

U mnogih liudei net rabot (Plural).

By many people no jobs.

Many people don't have jobs.

Correct: $У$ многих людей нет работы् .

U mnogih liudei net raboty (Singular).

At many people no job.

Many people don't have a job.

2) Папе и маме предложили новые работы.

Pape i mame predlozhili novye raboty (Plural).

Dad and mom were offered new jobs.

Correct: Папе и маме предложили новую работу.

Pape i mame predlozhili novuyu rabotu (Singular).

Dad and mom were offered a new job.

Even though the noun work has both a singular and a plural form in Russian (rabota raboty), the use of the plural form is restricted to very specific contexts. Below is one of the examples from the National Corpus of the Russian Language (www.ruscorpora.ru):

К сожалению, в современной российской психологии почти нет работ по психологии религии <...>. (Plural)

Unfortunately, in the modern Russian psychology there are almost no works on the psychology of religion. 
As seen from this example, the word rabota in its plural form (raboty) is mostly used in the meaning of printed works (literary or scientific) or art. To express the meaning of place of employment the singular form rabota should be used.

Interestingly, the mistakes found in my data in the number errors category were almost identical: incorrect use of the same noun "job/jobs". However, the two students who made this mistake were taking different classes with two different instructors and were working on different assignments.

\subsubsection{Adjectives for nationality}

Errors of this category accounted for $2.8 \%$ of all errors, with a frequency of 0.8 per 1000 words. In the example below, a student used an adjective instead of a noun to express a national identity:

жить как местные, чем американские

zhit kak mestnye, chem amerikanskie (adjective)

live like locals than like $\underline{\text { Americans }}$

Correct: жить как местные, чем (как) американиьь

zhit kak mestnye, chem (kak) amerikantsy (noun)

Errors like this are caused by the fact that English uses the same ethnic and national identity words as adjectives and nouns, while Russian clearly differentiates between adjectives and nouns in this category. 


\subsubsection{Negation}

Errors of this last category account for $2.8 \%$ of all errors, with a frequency of 0.8 per 1000 words.

Russian is a language that allows negative concord. As discussed in chapter 2, negative concord occurs when multiple negative constituents are used in one clause to express one semantic negation (Brown, 2005). Example below demonstrates negative concord in Russian:

Я никогда никуда не хожу.

Ya nikogda nikuda ne khozhu.

I never nowhere not go.

I never go anywhere.

Unlike Russian, which requires negative concord, Standard English lacks negative concord and double negatives cancel one another, which results in a semantically positive sentence. Thus, it is difficult for native English speakers to acquire a habit of using multiple negatives in Russian. Students tend to use only a single negation which is either incorrect or may have an unusual connotation and cause misunderstanding when communicating with native speakers.

One example of negation error from the students in this study was:

и ничего сделали

e nichego sdelali (single negation)

and nothing did

and did nothing 


\section{Correct: $и$ ничего не сделали}

\section{e nichego ne sdelali (double negation)}

\section{and nothing did not do}

As we can see in this example from a student's writing, a single negative here is incorrect. The grammatically correct way to express negation in that context is to use a double negative, i.e., two forms of negation in one clause.

While it is understandable that beginning students of Russian are prone to the negation errors, I was surprised to see these errors appear in the writing of students at the Intermediate High - Advanced levels.

\subsubsection{Summary of Research Question 1}

The first research question concerned the most common types of negative transfer overall in the writing of proficient students of Russian, regardless of the students' first language. In the above section I have described categories of negative transfer that emerged from coding errors and analyzing the data. I have also provided the breakdown of types of negative transfer for all participants based on the normed count per 1000 words for each student. Thirteen different categories were found. The most common categories were semantic extension, comma after an introductory phrase, lexical borrowings and the null subject errors. Each of these four categories with frequencies over 3 per 1000 words accounted for over $10 \%$ of the total number of errors. None of the other categories accounted for over $9 \%$. The next section compares the two groups, SLL 
and HLL, and describes the differences in types and amount of negative transfer used by participants in each group.

\subsection{Comparison of the SLL and HLL}

The second research question is concerned with the differences in types and amount of negative transfer used by HLLs vs. SLLs at comparable levels of proficiency. In order to answer the research question, this section, first, compares the percentages for the two groups of learners based on the normed counts. Second, this section provides a discussion of the individual variation within each group, based on the number of errors actually found in each student's writing and on number of words submitted by each participant. Number of words submitted by each student is the right measure for the variation discussion, because the individual contribution varied greatly and, therefore, certain individuals heavily affected the results. As mentioned before, the number of papers varied from 1 to 15 , and the amount of words from 206 to 3774.

The data analysis showed that $64.12 \%$ of all errors were found in the writing of the SLL group, and $35.88 \%$ of errors were found in the writing of the HLL group. Some categories of errors were associated with a group, SLL or HLL, and some were not. Figure 4.2.1 compares the percentages based on the normed counts for SLL and HLL groups. 
Figure 4.2 Types and amount of negative transfer used by HLLs vs. SLLs (percentages based on the normed counts).

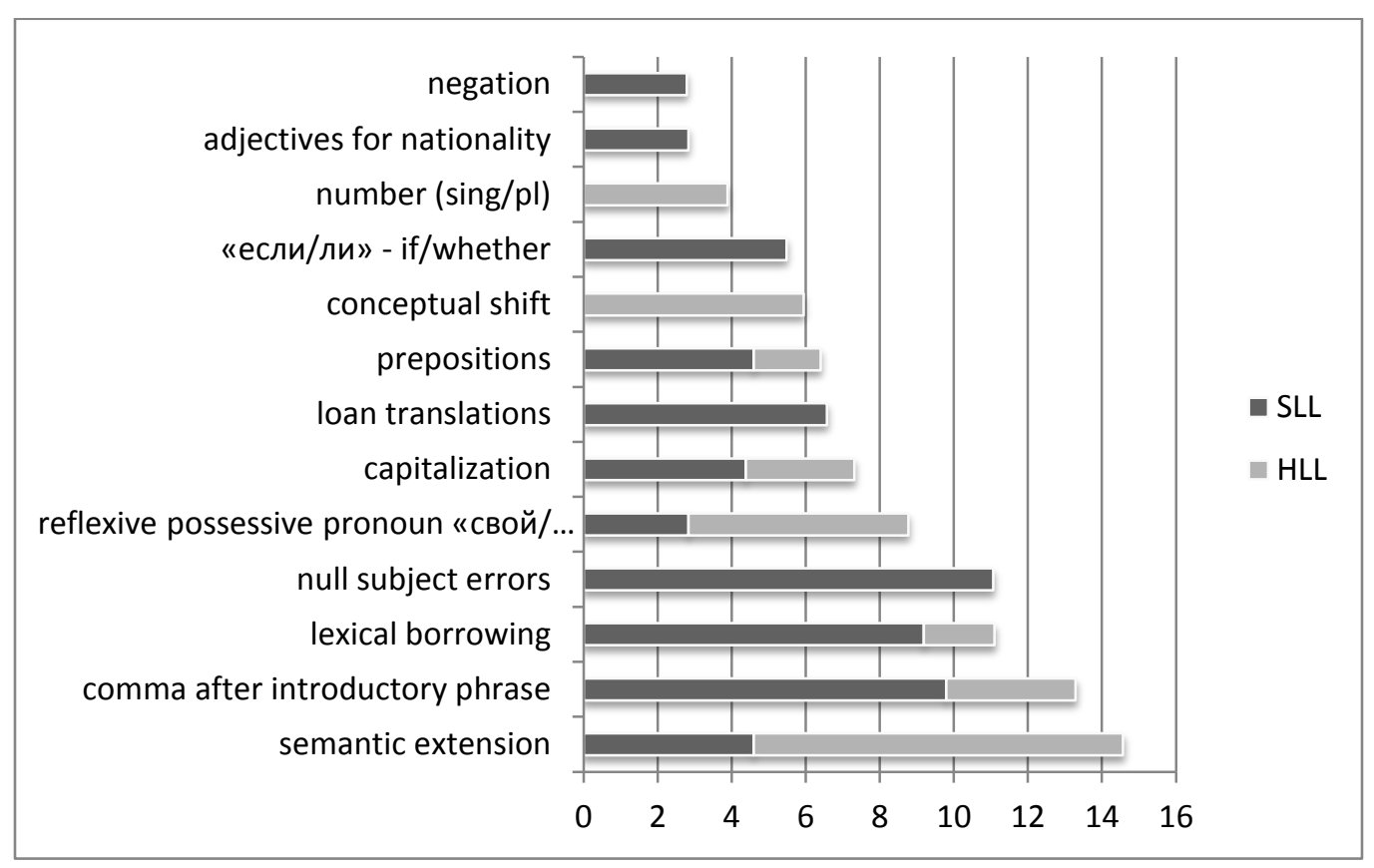

As seen from Figure 4.2.1, there are only two categories that do not include the SLL group: none of the participants in this group made errors of conceptual shift and number. On the other hand, the participants from the HLL group did not make errors in the following five categories: null subject, loan translations, conjunction if/whether, adjectives for nationality, and negation.

In the next section, I will discuss the specifics of each of the two groups. First, I will discuss categories limited to the HLL group, then categories limited to the SLL group, and, finally, categories that were shared by the two groups of participants. In the end, I will provide short description of the outliers, the participants who heavily affected the results. 


\subsubsection{Types and amount of negative transfer used by HLLs}

There were 6 heritage language learners participating in my study but the individual variation in contribution varied greatly. Overall, the HLL group contributed 45 papers, from the minimum of 5 papers by student \#10 to the maximum of 10 papers by student \#09. The total number of words provided by the students in this group was 8811 words. Specifically, the individual contribution ranged from the minimum of 595 words submitted by student \#13 to the maximum of 1979 words provided by student \#08.

As mentioned earlier, about $1 / 3(35.88 \%)$ of all errors found in the data were made by the participants in the HLL group. The most frequent negative transfer errors found in the writing of the HLL group were semantic extension, conceptual shift, reflexive possessive pronoun "svoj", number, and comma after an introductory phrase. The categories that were limited to the HLL group were conceptual shift and number errors.

Conceptual shift is a category particularly worth discussing, because, on the one hand, it was the second most frequent error for the heritage learners, but on the other hand, it was nonexistent in the writing of the second language learners.

The definition and the example of the conceptual shift errors were given earlier, in chapter 2 and in section 4.2 .9 of this chapter. Here I provide some details about the student who made the error that I used as an example of using a state verb instead of a processual reflexive verb 'rasstroilsya' ('got sad'), thus framing the emotion as a state rather than a process. The student who made this error was \#13, an immigrant who came to the US as a teenager and had been living and going to school in the U.S. for 5 years. 
According to Pavlenko (2002), heritage learners like the student described above are prone to conceptual shift from L1 to L2 based concepts. Acquisition of an additional language in adulthood and spending significant amount of time in the L2 community may, as Pavlenko explains, result in L1 attrition and lead to changes in conceptual representations (Pavlenko, 2002, p. 86).

Like the conceptual shift errors described above, number errors were also limited to the HLL group. There were two students, \#08 and \#13, who made number errors. Interestingly, the errors were almost identical: using word rabota (work, job) in its plural form (raboty) instead of a required singular form. However, the students who made the error attended two different classes with two different instructors and were working on different assignments. The only commonality between them was the fact that they were both heritage students. By the time of the research, student \#08 had been in the US for over 15 years. The student did not attend school in Russia, all education was received in the US (12 years in school, 3.5 years in college). Student \#13, as mentioned before, had 8 years of schooling in Russia and 5 years in the US. Thus, these students had very different experiences, but still made almost identical errors.

In sum, the categories of conceptual shift and number errors were found only in the writing of the HLL group. Conceptual shift likely occurs only with HLLs because it is a result of the first language attrition that occurs when immigrants have been immersed in a target language community for a significant amount of time (Pavlenko, 2002). As for the number errors, I do not see any reasons for this error category to be limited to only 
heritage speakers, but I simply did not encounter any number errors made by SLLs. It would be interesting to explore the issue with a larger sample.

\subsubsection{Types and amount of negative transfer used by SLLs}

There were 7 second language learners participating in the research. Overall, the SLL group contributed 9610 words in 56 papers. The individual contribution ranged from the minimum of 1 paper and 206 words by student \#04 to the maximum of 15 papers and 3774 words by student \#02. As mentioned earlier, the SLL group was responsible for $64.12 \%$ of all errors found in the data. Specifically, the following categories of errors were found exclusively in the writing of SLLs:

- null subject errors: 3.1 per 1000 words,

- loan translations: 1.9 per 1000 words,

- conjunction “yesli/li" (if/whether): 1.6 per 1000 words,

- adjectives for nationality: 0.8 per 1000 words,

- negation: 0.8 per 1000 words.

There were 12 instances of the null subject error found in the data: two instances by student $\# 02$, three instances by student $\# 05$, and seven instances by student $\# 06$. Student \#02 submitted the most words in the SLL group (3774), so it is not surprising that $10 \%$ of all transfer errors in the group were found in this student's writing. Students \#05 and \#06 will be discussed later, as they stand out from the group. In my experience, even though I have heard heritage students make null subject errors, it is the Englishbased learners of Russian that are more prone to this error. Since they began speaking, 
they have always used subjects in clauses. Thus, under the influence of English, learners of Russian tend to insert a subject even in contexts where the subject should be omitted in Russian.

There were 7 instances of loan translation errors found in the data: two by students \#02 and \#05, and one by students \#04, \#06, and \#07 each. Thus, there was a total of five students who made this error, more than in any other category. Loan translation is usually an idiom or a collocation directly translated into a target language. Collocations and idiomatic expressions are very frequent and at the same time very hard to translate appropriately even for proficient learners. It requires a very good command of a language to find an equivalent for an idiom; direct translation almost always sounds awkward and unnatural.

Like the null subject and loan translation errors described above, the conjunction "yesli/li" (if/whether) category was found exclusively in the writing of the SLL group. The errors in this category constituted $5.48 \%$ of all errors, with a frequency of 1.55 per 1000 words. There were 3 instances of this type of error. This error is more common in early drafts of work and in oral production. However, the frequency decreases in the written assignments where students have time to proof-read their work. It is the Russian Flagship Program requirement that home writing assignments should be self-checked and well-polished.

There were two other types of negative transfer errors that occurred exclusively in the writing of the SLL group: adjectives for nationality and negation. These categories are discussed below. 
Using adjectives for nationality instead of a required noun is a very common error at lower levels of proficiency and often goes away as learners progress. Thus, it is not surprising that there was only one instance of this error found in my data, in the writing of student \#06.

Interestingly, a lot of errors that are characteristic of lower level proficiency were found in the writing of student \#06. This student spent two years in a Russian-speaking country before having any formal instruction in Russian. Thus, most of the experience communicating in Russian for this student came before the formal training and the student may have fossilized some of the errors that otherwise would have been cleared early.

Negation errors are also more common at lower levels. In my data there were 3 instances of this error, all by the same student, \#02. As described earlier, this student contributed twice as many words as the next most productive student in the group (3774 words). That is why it is not surprising that errors by that student were found in many categories. However, it is important to add that this student was also special in another way. Student \#02 had been studying Russian intensively for over five years. The student was also taking overloads of other classes, pushing to graduate from college as quickly as possible. Thus, the student may not have allowed time for language skills be fully processed and acquired. A language like Russian takes time and requires a lot of work and practice, and students sometimes do not put enough time to reach a high accuracy level. 
In sum, there were 5 error categories made only by SLLs: null subject errors, loan translations, conjunction "yesli/li" (if/whether), adjectives for nationality, and negation. A small sample does not allow drawing generalizations or providing clear reasons for these errors being exclusive to SLLs. However, possible reasons might include the following:

- SLLs are more prone to null subject errors because their first language, English, expresses subjects obligatorily, because there are no clear-cut rules in Russian about overt and covert subjects and omitting a subject depends on the context, and because unlike heritage learners, SLLs cannot rely on their intuition of "it just doesn't sound right".

- Similar reasons are possibly at work for the loan translation errors. Idioms and collocations are very hard to translate. SLLs don't have an advantage of growing up hearing Russian, so they are much less exposed to the Russian idioms and collocations. But they may be more familiar with the idiomatic expressions in English than their HLL counterparts. Therefore, when the SLLs attempt to use an idiom when communicating in Russian, they most likely have nowhere else to go but to translate the phrase directly.

- Conjunction "yesli/li" errors are notorious, since almost every learner of Russian makes this type of error. I was surprised to find that in my data this error only came from the SLLs. It would be interesting to focus on this error category and explore it in a study with a bigger sample. 
- Adjectives for nationality and negation errors are also characteristic of SLLs rather than HLLs. These grammatical concepts are usually less subject to attrition, than, for example, the case system, so heritage learners are unlikely to make errors in these categories.

\subsubsection{Shared Categories}

In the sections above, I have discussed categories limited to either HLL or SLL group. In this section I will discuss categories found in the writing of both groups. There were six categories shared by the HLL and SLL groups: semantic extension, comma after an introductory phrase, lexical borrowings, reflexive possessive pronoun "svoj", capitalization, and prepositions.

Interestingly, most of the shared categories contain mostly equal number of errors made by each group. In the semantic extension category there were 4 errors made by the SLL participants and 4 errors made by HLL participants. However, in the HLL group, 3 of the 4 errors came from one student. Student \#13 attended elementary and middle school in Russia, and then moved to the US to live in an English-speaking household. This student completed high-school education in English. At the time of the research, the student was a college freshman. The other heritage learner who made a semantic extension error, \#12, only had 3 years of schooling in Russia and moved to the US right after elementary school. The rest of the education had been in English until the student joined the Russian Flagship Program at PSU 1.5 years before the time of the research. After joining the program, the student added a variety of Russian language activities to 
the schedule in addition to spending time with Russian-speaking friends. However, despite their differences, both students seem to have been dominant in English by the time they participated in the research.

In the comma after an introductory phrase category, four SLLs made 6 errors and four HLLs made 5. All four HLL students had received at least 3 years of schooling in Russia or a Russian-speaking country and at least 5 years of schooling in English. This error was the most widespread among the HLL group. In the SLL group all four students had started learning Russian a long time ago and all four had more than a year-long break from the language. In sum, a comma after an introductory phrase was a very common error that both groups of learners seemed to be prone to.

There was only one student making reflexive possessive pronoun "svoj" errors in each group. For the HLL group it was student \#13 and for the SLL group it was student \#06. Both of these students will be described in detail later as participants who heavily affected the results.

There was an equal number of occurrences of capitalization errors in each group. In the SLL group the two errors were made by students \#03 and \#07. Both of these students, despite having long histories of learning Russian, still made mistakes that are typically characteristic of lower proficiency levels. In the HLL group the two errors were made by students \#09 and \#10. Both students have been living in the US for 10-11 years and both were in their second year in the program. I believe if asked, the students would be able to explain the difference between capitalization rules in Russian and English. However, when writing they did not apply the rule consistently. 
The last two of the shared categories, lexical borrowings and preposition errors both had three SLL students responsible for 6 errors and one HLL student responsible for one error in each category. Comparing the ratio of SLL vs. HLL in a study with a larger sample is a question that future studies might want to pursue.

\subsubsection{Outliers: the unusual participants}

There were a few students who heavily affected the results. I will not provide specific demographic information about participants and their language experiences because I want to maintain their anonymity. However, I will mention particular conditions that seem likely to correspond to a learner making a particular error.

In the HLL group the most outlying participant was student \#13. This participant was responsible for $41 \%$ of all transfer errors found in the writing of the HLL group, even though this student submitted the lowest number of words (595 words; the mean amount of words per participant in the HLL group was 1468). The student was born in Russia, received 8 years of schooling there and by the time of participating in the research had been living in the US for 5 years attending American schools (high-school and college).

Interestingly, five other participants from the HLL group had been living in the US longer (from 8 to 15.5 years) and received less schooling in Russia (from 0 to 5 years). However, student \#13 was the only one who had moved into an English-speaking household upon arriving in the US. Other participants lived in Russian-speaking households, at least until they left for college. Thus, student \#13 did not have an 
opportunity to maintain Russian, except for occasional conversations with family and friends in Russia. It could be, then, that moving from a Russian-speaking environment to the English-speaking household and predominantly English-speaking environment resulted in the student's Russian being significantly influenced by English.

In the SLL group the most outstanding participants were student \#05 and student \#06. Student \#05 was responsible for $29 \%$ of all transfer errors found in the writing of the SLL group. The student made errors in 7 out of 11 categories. This student started learning Russian about 10 years ago, lived in a Russian-speaking country for almost two years, using the language both at work and at home. At the time of participating in this research, student \#05 was taking advanced level Russian classes after several years of not using much Russian. In the SLL group, student \#05 had spent the most time in a Russianspeaking country, but received the least formal training in the language. The student reported that members of the household in a Russian-speaking country never corrected the student's mistakes. Thus, being a "street learner" with no formal instruction and no feedback on language performance possibly led to fossilization of errors. A long break in Russian before coming to the Russian Flagship program might have also added to the student's Russian being more heavily affected by English. However, I am reluctant to generalize on the bases of such a small sample.

Student \#06 was responsible for approximately 22\% of all transfer errors made by SLL group. However, the majority of this student's errors (64\%) were in one category, null subject errors. As mentioned before, student \#06 had one year of formal instruction in Russian, spent two years in a Russian-speaking country, and then took a few advanced 
Russian classes. Thus, most of the student's experience in communicating in Russian came before the student's major formal training. During the quarter of data collection, this student was taking a class where a lot of assignments were based on description. As discussed in detail earlier, descriptive sentences often have unexpressed subjects in Russian. This is difficult for native English speakers, because English does not allow subjectless sentences. Being a very hardworking and responsible student, participant \#06 submitted every single assignment, more than other students in that class: 1250 words, compared to 919,595 , and 206 words respectively by three other students taking the same class. Thus, even though student \#06 stands out as making the most mistakes in one category, it is in part due to the fact that this student contributed a lot of assignments to the data.

\subsubsection{Summary of Research Question 2}

The second research question concerned the differences in types and amount of negative transfer used by HLLs vs. SLLs at comparable levels of proficiency. In the above section I have compared the two groups of learners. I have discussed categories limited to each group as well as shared categories. I have also provided the discussion of the individual variation within each group. In the end, I have provided a short description of the outliers, one heritage and two second language learners who heavily affected the results.

In sum, the analysis showed that SLLs made more transfer errors that HLLs (64\% vs. $36 \%$ ). SLL participants made errors in 11 out of 13 categories, while HLLs made 
errors in 8 out of 13 categories. Thus, it appears that the SLL participants of the research were more prone to transfer errors than HLLs, but the small sample does not allow making generalizations. There were 6 categories shared by the two groups: semantic extension, comma after an introductory phrase, lexical borrowings, reflexive possessive pronoun "svoj”, capitalization, and prepositions.

\subsection{Conclusion}

This chapter has presented a detailed analysis of the data and a discussion of the major findings. The next chapter puts together a summary of the major findings of the data analysis, possible implications of these findings, and the limitations of the study. 


\section{CHAPTER 5}

\section{CONCLUSION}

In the previous chapters, I analyzed the body of existing research literature related to the phenomenon of language transfer and transfer errors in general and to two groups of learners in particular, second language and heritage language learners of Russian and the main deficiencies of each group. I described the goals of my thesis study and the method of data collection and data analysis. Then I presented the results of the analysis of negative transfer errors found in the written work of the participants of my research and discussed the findings. In this chapter, I briefly review the purpose of this study, present the summary of the major findings and discuss the implications of these findings as well as the limitations of the study. Finally, I offer suggestions for future research related to the study of negative transfer in discourse of advanced learners of Russian.

\subsection{Purpose of the study and summary of findings}

The main purpose of this thesis study was to explore the phenomenon of negative transfer from English in the writing of proficient heritage vs. second language learners of Russian. Specifically, the study addressed the following questions:

(1) What are the most common types of negative transfer from English that occur in the writing of students of Russian at the Intermediate High - Advanced levels?

(2) Are there differences in types and amount of negative transfer used by HLLs vs. SLLs at comparable levels of proficiency? If so, what are the differences? 
The research was conducted at the Russian Flagship Program at Portland State University. Participants were 13 advanced students of Russian, 6 heritage and 7 second language learners of Russian. The study analyzed the written work of students completed during one quarter. Errors were coded into 13 categories that emerged from the data and were, in fact, consistent with some of the results of transfer studies described in the literature.

There was a great deal of variation in the amount of writing contributed by each participant. For quantitative analysis, it was, therefore, important to norm the count per 1000 words for each student for each type of error, so that no individual influenced the analysis disproportionally. This analysis answered the research question 1. Specifically, the results found that none of the errors were more frequent than 5 per 1000 words. The most common categories were semantic extension, commas after an introductory phrase, lexical borrowings and null subject errors. Each of these four categories with frequencies over 3 per 1000 words accounted for over $10 \%$ of the total number of errors. Other types of errors that occurred but were less common were reflexive possessive pronoun “свой/svoj”, capitalization, loan translation, prepositions, conceptual shift, conjunction “if/whether", number errors, adjectives for nationality, and negation errors.

The results also demonstrated that some categories of errors were associated with only one group, SLL or HLL, and some were not. Specifically, the categories of null subject errors, loan translations and negation errors were found only in the writing of second language learners. There were only two categories limited to the group of heritage language learners: conceptual shift and number errors. The categories of comma after an 
introductory phrase, semantic extension and lexical borrowings were found in writing of both groups of students.

Overall, four out of 13 categories that emerged from my data were consistent with the categories identified in Pavlenko and Jarvis 2002 study: lexical borrowing, loan translation, word order transfer, and semantic extension. However, Pavlenko and Jarvis described examples of semantic extension found in the narratives of only HLLs (e.g. fotoapparat vs. camera); my data showed that SLLs were prone to this type of error as well.

In order to compare the SLL and HLL groups, I had originally planned to run a test of statistical difference to see if the differences in categories of transfer errors between the two groups of learners were significant. However, the study had an unexpectedly small number of participants and errors, resulting in the numbers being too low for statistical tests. Instead, I only described the nature and the frequency of errors. In the end, I provided a short description of outliers, one HLL and two SLL participants who made a heavy impact on the results.

In summary, SLL made more transfer errors that HLLs (64\% vs. 36\%). SLL participants made errors in 11 out of 13 categories, while HLLs made errors in 8 out of 13 categories. Thus, it appeared that SLL participants of the research were more prone to transfer errors than HLLs, but the small sample does not allow making generalizations. There were 6 categories shared by the learners: semantic extension, comma after an introductory phrase, lexical borrowings, reflexive possessive pronoun "svoj", 
capitalization, and prepositions. Although there were a few outlying participants, fitting the HLL or SLL category still appeared to matter more than individual differences.

It has been argued in the literature that transfer is not a unidirectional influence but rather, it is often bidirectional and influences person's both L1 and L2 (Pavlenko \& Jarvis, 2002; Isurin, 2005; Marian and Kaushanskaya, 2007). However, my thesis research was inspired by my teaching experience, and for my pedagogical goals the influence of Russian on English was not relevant at that point. Therefore, in my study I focused exclusively on one dimension of the transfer, from English to Russian.

\subsection{Implications}

Although a number of studies have examined negative transfer from English into Russian, and other studies have compared the performance of heritage language learners (HLLs) to second language learners (SLLs), little research has investigated the phenomenon of negative transfer in the writing of both HLLs and SLLs and compared the two groups. Thus, this study employed an exploratory approach to empirically investigate the differences in language transfer between the two groups of learners. Despite the potential limitations (covered in the next section), this study provided some important insights about the phenomenon of negative transfer from English into Russian. Specifically, the study showed the most common types of negative transfer from English that occurred in the writing of students of Russian at the Intermediate/High to Advanced level of proficiency. 
The findings of this study are important to several groups. First, as a study of errors, it is important to Russian language teachers. Being more aware of transfer errors, having a deeper understanding of which differences between Russian and English promote those errors may allow teachers to address those errors better and, potentially, even prevent some of them. For example, working on this research has already made me more aware of the negative transfer and allowed me to incorporate that knowledge into my teaching. When I was teaching the intensive first year Russian recently, I noticed that my students started using commas after an introductory phrase as soon as they were able to write in sentences. I consider acquiring punctuation as important as learning vocabulary and grammar, so I chose to address the issue and draw students' attention to this difference in punctuation between English and Russian. I believe it helped my students learn the rule early on, the error became much less frequent, and the students will be less likely to carry on this error through years, all the way to their advanced level classes.

Another example of this study positively affecting my teaching happened during the quarter following the data collection. Working on the analysis I realized that one of my students was constantly making one type of error, with the reflexive possessive pronoun "свой/svoj", a type that I've seen in my data. Working on my research I have studied the literature on this type of error, so I knew how to explain it to the student. I provided the student with comparison of the rules in English and Russian, helped her understand the difference, and provided several examples and exercises to practice. I watched the student closely for the rest of the year and I did not see that type of error 
being made again. Thus, from my experience, teachers being aware of transfer errors and addressing them consistently leads to more productive teaching and improvement in students' writing.

Another important pedagogical implication comes from the demonstration of commonality between the SLLs and HLLs. The results of my study showed that out of 13 transfer error categories, 6 categories (about 50\%) were shared by the SLL and HLL groups. It shows that these two group of learners are not as different from each other as it might seem (at least, at the higher level of proficiency). So, having heritage and second language learners in one class can, indeed, be appropriate and does not constantly require two different sets of activities. For example, the six types of errors that were shared by the two groups might be worth pedagogical intervention for the whole class.

In addition to teachers, this study can also benefit learners of Russian themselves. Learners can be asked to analyze typical errors so they can gain awareness, be more efficient in self-correction and reduce their own errors. For example, after I compiled a list of transfer error categories that emerged from the data, I created an exercise for my students. I wrote a list of sentences that included different transfer errors. Then I asked my students to work on the exercise in pairs, trying to find and correct mistakes. Then we discussed their answers in class. I was pleased to see that employing this exercise a few times during the quarter helped to make students more aware of the issues and decrease amount of errors in their writing.

This research was also a small but hopefully meaningful contribution to the field. This study looked at the possible differences in types and amount of negative transfer 
used by heritage learners of Russian vs. second language learners at comparable levels of proficiency. Although no definitive conclusions were possible, the study provided the linguistic community with questions for further research (discussed in the next section).

In sum, I expect that the findings of this research will be of use, first of all, for the language instructors that teach in the Russian Flagship Program at PSU. Primarily, I expect that it will continue to help me to better understand and then address the errors that my students make. I also hope that the results of this study will be useful more generally in teaching Russian in the United States, for teachers working with both heritage and second language learners.

\subsection{Limitations and future research}

This study contributes to our general understanding of the phenomenon of negative transfer and the particular transfer errors HLLs and SLLs of Russian may be subject to. However, as with all studies, there are certain limitations to this research.

First, only one context of language use, academic writing, was the focus of this study. Second, the sample used to obtain the data was small, with only 13 subjects. Third, all participants were students of the same language program. These limitations do not allow making generalizations from the results. However, if a similar research could be conducted in other Russian language programs, comparing the findings could possibly allow for more generalization.

Also, conducting studies of negative transfer in oral discourse and in in-class (timed, unplanned, not proofread) writing and comparing the results with studies of 
transfer in academic writing (non-timed, planned, proofread) would allow us to better understand the phenomenon of negative transfer.

Additionally, a comparison with a control group of monolingual native speakers residing in Russia would have allowed to more strongly confirm the presence of negative transfer. However, for the nature and the length of this research obtaining a control group was not feasible. Future studies could benefit from that addition.

There is also a limitation from the subjective method employed in data and results interpretations. Even though before coding the main body of the data, I discussed the error coding process with an experienced instructor of Russian who is a native speaker of English, and after the training session we performed an inter-rater reliability check, the interpretations of the data collected in this are solely my own. It is possible that other researchers could have coded the data somewhat differently. Additional research with more coders for the data and the development of a more detailed coding rubric would be useful for reliable coding.

Despite the limitations of the study and the challenges of studying diverse groups, learning about transfer errors is a valuable undertaking. Errors are inevitable in the language learning process and should be treated as a window into learner's interlanguage, and not necessarily as a deficiency. Or as one Russian saying puts it, "Не ошибается только тот, кто ничего не делает” - “Only those who do nothing make no mistakes." 


\section{REFERENCES}

American Councils' Overseas Language Flagship Programs. Russian Flagship

Programs. Retrieved from http://flagship.americancouncils.org/russian/

Andrews, D. R. (2001). Teaching the Russian heritage learner: Socio- and psycholinguistic perspectives. The Slavic and East European Journal, 45, 519530.

Anson, C. M., Schwegler, R. A., \& Muth, M. F. (1999). The Longman writer's companion. New York, NY: Addison Wesley Longman.

Argyri, E. \& Sorace, A. (2007). Crosslinguistic influence and language dominance in older bilingual children. Bilingualism: Language and Cognition, 10, 79-99.

Berman, R., \& Slobin, D. I. (1994). Relating events in narrative: A cross linguistic developmental study. Hillsdale, NJ: Lawrence Erlbaum.

Brinton, D. M., Kagan, O., \& Bauckus, S. (Eds.). Heritage language education: A new field emerging. New York, NY: Routledge.

Brown, S. (2005). Negative concord in Slavic and Attract All-F. In S. Brown and A. Przepiórkowski, (Eds.), Negation in Slavic (pp. 71-104). Bloomington, IN: Slavica Publishers.

Comer, W. (2009). Mind the Gap: English L2 Learners of Russian and the Null Possessive Pronoun. Russian Language Journal, 59, 79-99.

Davidson, D. E. (2009). Creating global professionals through new strategies in Russian language instruction. Discourse. Newsletter of the Language Flagship, spring 2009, 3 . 
Driagina, V., \& Pavlenko, A. (2007). Identity repertoires in narratives of advanced American learners of Russian. In Z. Hua, P. Seedhouse, L.Wei, \& V. Cook (Eds.), Language learning and teaching as social interaction (pp. 103-125). New York: Palgrave Macmillan.

Gass, S. M., \& Selinker, L. (Eds.). (1992). Language transfer in language learning (Revised ed.). Philadelphia, PA: John Benjamins Publishing Company.

Gass, S. M., \& Selinker, L. (2008). Second language acquisition: An introductory course. (3d ed.). New York, NY: Routledge.

Golonka, E. M. (2006). Predictors revised: Linguistic knowledge and metalinguistic awareness in second language gain in Russian. The Modern Language Journal, 90, 496-505.

Gor, K. \& Cook, S. (2010). Nonnative processing of verbal morphology: In search of regularity. Language Learning, 88-126.

Gor, K., Cook, S., Malyushenkova, V., \& Vdovina, T. (2009). Verbs of motion in highly proficient learners and heritage speakers of Russian. The Slavic and East European Journal, 53, 386-408.

Gordishevsky, G. \& S. Avrutin (2005). Optional omissions in an optionally null subject language. In J. van Kampen and S. Baauw (eds.), Proceedings of the GALA conference, Utrecht.

Hacker, D. \& Sommers, N. (2011). A writer's reference ( $7^{\text {th }}$ ed.). Boston: Bedford/St. Martin's. 
Hasko, V. (2009). The locus of difficulties in the acquisition of Russian verbs of motion by highly proficient learners. The Slavic and East European Journal, 53, 360-385.

Hopp, H. (2009). Ultimate attainment in L2 inflection: Performance similarities between non-native and native speakers. Lingua, 120, 901-931.

Isurin, L. (2007). Teachers' language: L1 attrition in Russian-English bilinguals. The Modern Language Journal, 91, 357-371.

Isurin, L. \& Ivanova-Sullivan, T. (2008). Lost in between: The case of Russian heritage speakers. Heritage Language Journal, 6, 72-104.

Kagan, O. \& Dillon, K. (2001). A new perspective on teaching Russian: Focus on the heritage learner. The Slavic and East European Journal, 45, 507-518.

Kagan, O. \& Dillon, K. (2006). Russian heritage learners: So what happens now? The Slavic and East European Journal, 50, 83-96.

Kubota, R. (1998). An investigation of L1-L2 transfer in writing among Japanese university students: Implications for contrastive rhetoric. Journal of Second Language Writing, 7, 69-100.

Marian, V. \& Kaushanskaya, M. (2007). Cross-linguistic transfer and borrowings in bilinguals. Applied Psycholinguistics, 28, 369-390.

Odlin, T. (1989). Language transfer: Cross-linguistic influence in language learning. Cambridge: Cambridge University Press.

Pajoohesh, P. (2007). A probe into lexical depth: What is the direction of transfer for L1 literacy and L2 development? Heritage Language Journal, 5, 117-146.

Pavlenko, A. (2000). L2 influence on L1 in Late Bilingualism. Issues in Applied 
Linguistics, 11/2, 175-205.

Pavlenko, A. (2002). Conceptual change in bilingual memory: A Neo Whorfian approach. In F. Fabbro (Ed.), Advances in the neurolinguistics of bilingualism (pp. 69-94). Udine: Forum.

Pavlenko, A. (2008). Structural and conceptual equivalence in the acquisition and use of emotion words in a second language. The Mental Lexicon, 3, 91-120.

Pavlenko, A. \& Driagina, V. (2007). Russian emotion vocabulary in American learners' narratives. The Modern Language Journal, 91, 213-234.

Pavlenko, A. \& Jarvis, S. (2002). Bidirectional transfer. Applied Linguistics, 23, 190-214.

Polinsky, M. (2000). The composite linguistic profile of speakers of Russian in the US. In O. Kagan \& B. Rifkin (Eds.), The learning and teaching of Slavic languages and cultures (pp. 437-65). Bloomington, IN: Slavica.

Polinsky, M. (2008a). Gender under incomplete acquisition: Heritage speakers' knowledge of noun categorization. Heritage Language Journal, 6, 40-71.

Polinsky, M. (2008b). Heritage language narratives. In D. M. Brinton, O. Kagan, \& S. Bauckus (Eds.), Heritage language education: A new field emerging (pp. 149164). New York, NY: Routledge.

Polinsky, M., \& Kagan, O. (2007). Heritage languages: In the 'wild' and in the classroom. Language and Linguistics Compass, 1, 368-395.

Portland State University. Russian Flagship Partner Program. Retrieved from http://www.pdx.edu/russian-flagship/flagship-program

Portland State University. University Studies. Retrieved from http://www.pdx.edu/unst/ 
Rifkin, B. (1995). Error gravity in learners' spoken Russian: A preliminary study. The Modern Language Journal, 79, 477-490.

Rosengrant, S. (1987). Error patterns in written Russian. The Modern Language Journal, $71,138-146$.

Rubinstein, G. (1995). On acquisition of Russian cases by American classroom learners. International Review of Applied Linguistics in Language Teaching (IRAL), 33, 934.

Rubinstein, G. (1995). On case errors made in oral speech by American learners of Russian. The Slavic and East European Journal, 39, 408-429.

Shardakova, M. (2005). Intercultural pragmatics in the speech of American L2 learners of Russian: Apologies offered by Americans in Russian. Intercultural Pragmatics, $2-4,423-451$.

Shteyngart, G. (2004). The new two-way street. In T. Jacoby (Ed.), Reinventing the melting pot: The new immigrants and what it means to be American (pp. 285-92). New York, NY: Basic Books.

Thompson, I. (1977). Russian word order: A comparative study. The Slavic and East European Journal, 21, 88-103.

Valdés, G. (2000). Spanish for native speakers: AATSP professional development series handbook for teachers K-16 (Vol. 1). New York, NY: Harcourt College Publishers. 


\section{Appendix A}

\section{Language Background Questionnaire}

\section{Language Background Questionnaire}

1. Your name:

2. Which of these best describes you? (circle one)

a) a second language learner of Russian (you grew up speaking and hearing a language rather than Russian)

b) a heritage learner of Russian (you grew up speaking and/or hearing Russian)

c) other (please, specify)

3. In what situations, if any, do you write in Russian (including emails, notes, etc.)?

4. Do you read in Russian? If yes, please, specify what you read and how often (searching the Internet counts).

5. In your life, what language did you speak first?

6. Do you speak any other languages besides Russian and English?

7. How many years of schooling have you received

a) in Russian

b) in English

c) in other languages (please, specify)

8. How long have you been living in the United States?

9. Is there anything else you would like me to know about your language background?

Thank you! 


\section{Appendix B}

\section{Consent form for Questionnaire}

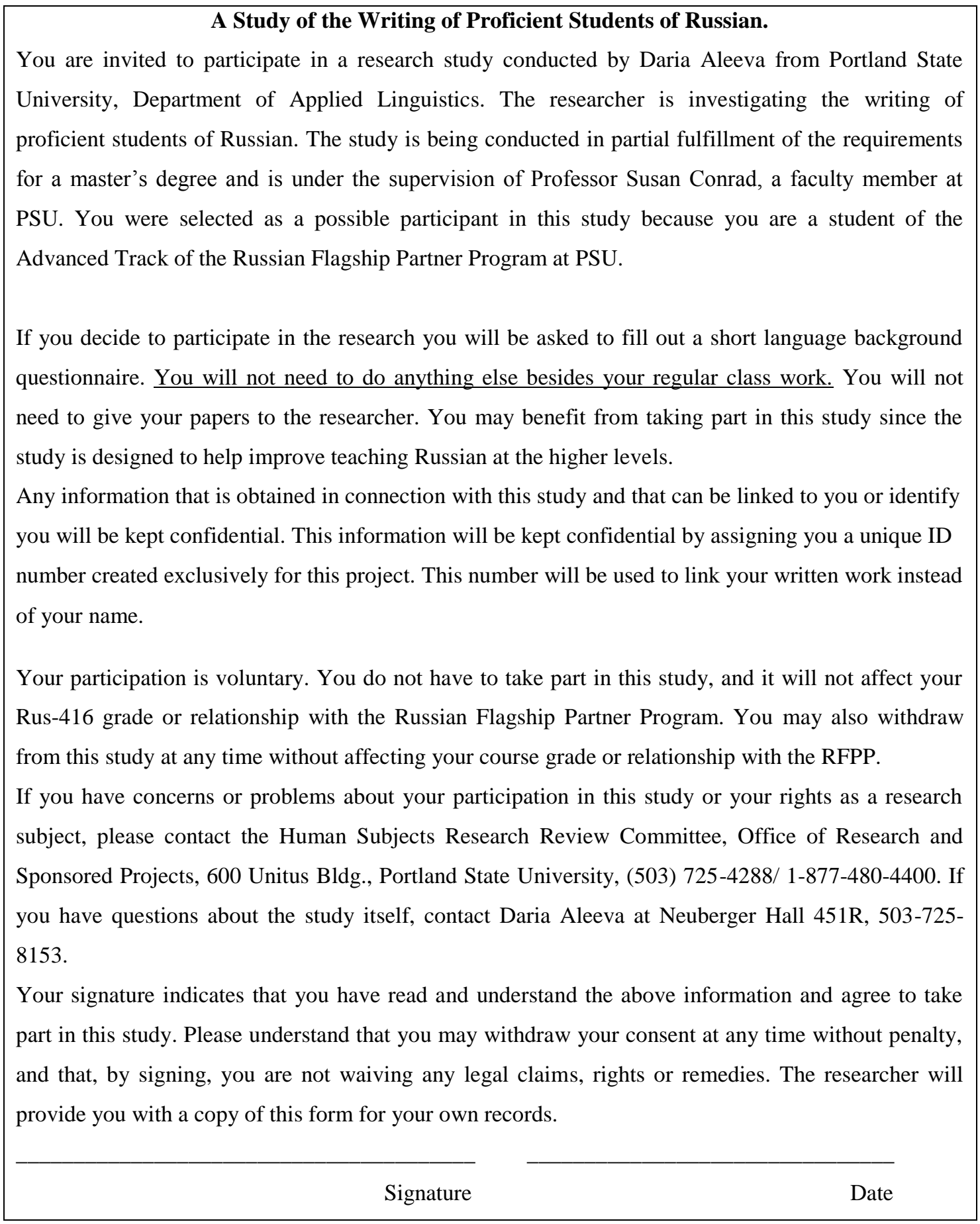


Appendix C

Sample of Assignments (not complete list)

1) Write your own definition of sustainability. /Своими словами напишите определение понятия “устойчивое развитие”.

2) Write an essay about ecological problems in Russia (Neva River in Saint-Petersburg). / Экологические проблемы России: река Нева в Санкт-Петербурге.

3) Imagine: You are an American Fulbright scholar in the University of Cairo. Write a post about the current situation in Egypt for your blog. What is happening? How does the uprising affect your daily life there? (Personal narrative about the uprising in Egypt in January 2011.) / Вы - американский стипендиат программы Фулбрайт в университете Каира. Напишите небольшую заметку для своего блога о том, что происходит сейчас в Египте.

4) Write a paragraph: How the current situation in Egypt is either similar to or different from the Iranian revolution of 1978-79. Сравните ситуацию в Египте сейчас и Исламскую революцию в Иране в 1978-79 годах. Напишите небольшую заметку о том, что между ними общего или в чём между ними различия.

5) Write a letter to the president of Russia in defense of Lake Baikal. / Напишите письмо в защиту Байкала президенту России.

6) Write an annotation of an article "Etymology as a weapon of ideology" by Bukina E. / Напишите аннотацию статьи Букиной Е. «Этимология как оружие идеологии». 7) Look at the 2 portraits of Iranian leaders. Describe the pictures and compare them. / Рассмотрите портреты двух иранских правителей. Опишите и сравните их.

8) Write a paragraph in response to the following question: Do you agree that people who speak only one language have a "poorer intellectual life" than those who speak at least two languages? / Согласны ли вы с мнением, что у людей, говорящих только на родном языке, интеллектуальная жизнь беднее, чем у людей, говорящих, как минимум, на двух языках? 